\title{
DETAILED TABLE OF CONTENTS
}

Table of Cases before the European Commission. xxxvii

\section{BOOK ONE}

\section{PART 1}

\section{INTRODUCTION}

\section{Chapter 1}

Overview

1. Introduction ........................................................................................ 1

2. The history of European merger control................................................... 5

3. The legal basis of the Merger Regulation ...................................................... 12

4. Objectives and general principles ................................................................... 12

5. The residual application of Articles $101 \mathrm{TFEU}$ and Article 102 TFEU to concentrations........................................................... 13

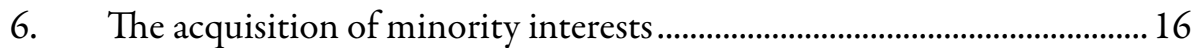

7. Merger control at national level ..................................................................... 19 


\section{Chapter 2}

The evolution of EU merger control since 1990

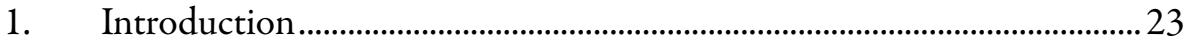

2. The main phases of evolution in the application of the Merger

Regulation

2.1 The Merger Review 2002-2004 and new 'recast' Merger Regulation 2004.................................................................................. 31

2.2 Revised substantive test ..................................................................... 36

2.3 The revised referral system .................................................................. 37

2.4 Procedural changes under the Merger Regulation since 2004.... 41

2.5 Recent judicial developments.

\section{Chapter 3}

Implementation and Enforcement ........................................................51

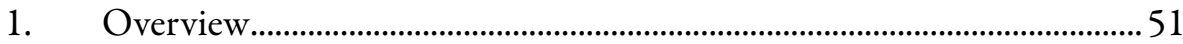

2. The Merger Regulation ........................................................................ 52

3. The Implementing Regulation ....................................................................52

4. The Commission's Notices and Guidelines ...............................................55

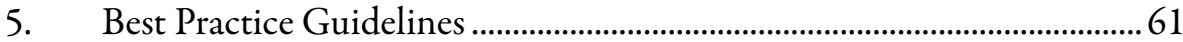

6. The framework of decision-making in merger cases ...................................62

7. The operational handling of merger cases by DG Competition ..............64

8. The system of 'checks and balances' ...............................................................65

\section{PART 2}

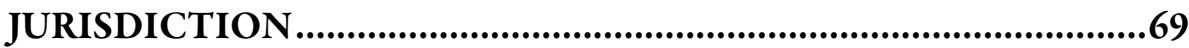

\section{Chapter 1}

Introduction

1. Exclusivity of the European Union's jurisdiction ......................................69

2. Jurisdiction under the EEA Agreement ......................................................70

3. Territorial scope of application of the Merger Regulation......................... 71

4. Jurisdiction in the United Kingdom under the Withdrawal Agreement 


\section{Chapter 2}

1. The concept of a concentration.................................................................... 75

2. $\quad$ Mergers - Article 3(1)(a) ..........................................................................

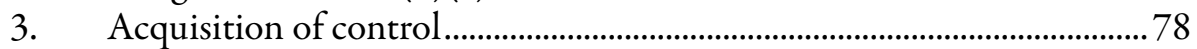

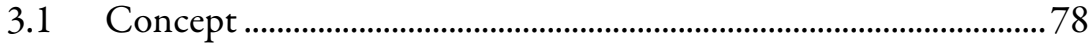

3.1.1 Person or undertaking acquiring control ........................79

3.1.2 Acquisitions by a State or state-owned undertakings ...................................................................... 81

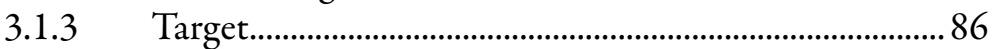

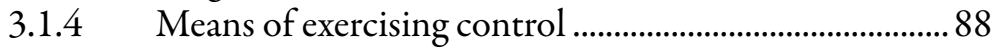

3.1.5 Acquisition of control on a lasting basis ........................ 92

3.1.6 Internal restructuring .........................................................97

3.2 Sole control ..................................................................................97

3.2.1 Majority of voting rights .................................................. 98

3.2.2 Minority shareholdings conferring legal control ..........98

3.2.3 Situations leading to negative sole control .................... 99

3.2.4 Minority shareholdings conferring de facto sole control ..............................................................................99

3.2.5 Control by other means...................................................101

3.3 Joint control ......................................................................................... 101

3.3.1 Equality in voting rights..................................................102

3.3.2 Veto rights over strategic decisions..................................102

3.3.3 Joint exercise of voting rights ..........................................105

3.3.4 De facto joint control ........................................................106

3.3.5 Casting votes.......................................................................109

3.4 Changes in structure and quality of control.................................109

3.5 Interrelated transactions ...................................................................111

3.5.1 Interrelated transactions linked by conditionality.....112

3.5.2 Staggered transactions: Article 5(2) subparagraph 2 Merger Regulation ................................118

3.5.3 Series of transactions in securities ..................................120

3.6 Situations where no concentrations arise, Article 3(5)................121

3.6.1 Financial institutions ......................................................121

3.6.2 Office-holders such as insolvency receivers ...................123

3.6.3 Financial holding companies..........................................123

3.7 Termination of jurisdiction due to abandonment of transaction 


\section{Chapter 3}

Joint ventures

1. Introduction: application of the Merger Regulation to joint ventures ..................................................................................................... 127

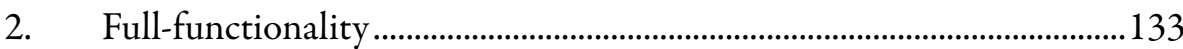

2.1 Activity on the market - Activities beyond one specific function for the parent companies.....................................................134

2.2 Sufficient resources and personnel .................................................136

2.3 Supply relationship......................................................................... 138

3. Performing the functions on a lasting basis ................................................ 142

4. Changes in the activity of a joint venture …………………………….......144

4.1 Changes in the activity of a full-function joint venture................144

4.2 Joint venture becoming full-function.............................................145

\section{Chapter 4}

European Union dimension................................................................147

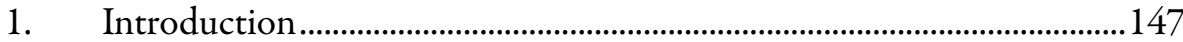

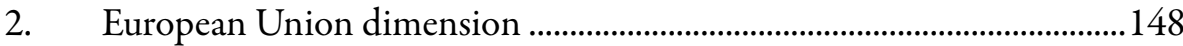

3. Undertakings concerned .........................................................................150

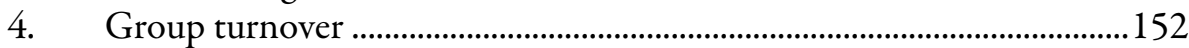

4.1 Article 5(4), (5) ......................................................................... 153

4.2 Differences between the concept of a group under Article 5(4) and the concept of control under Article 3 .............156

5. Calculation of turnover ........................................................................157

5.1 Principles of calculation of turnover.................................................157

5.2 Geographic allocation of turnover .................................................163

5.3 Rules for specific sectors, Article 5(3) ............................................ 165

\section{Chapter 5}

Referrals

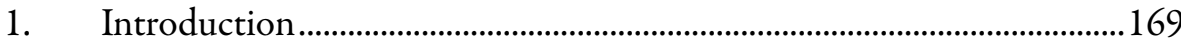

2. Referrals to Member States according to Article 9 ..................................172

2.1 Substantive criteria ........................................................................ 173

2.2 Procedural aspects........................................................................175

2.3 Scope of the receiving Member State's jurisdiction .......................176

3. Pre-notification referrals to Member States pursuant to Article 4(4)..178 


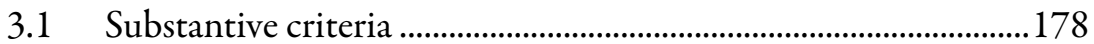

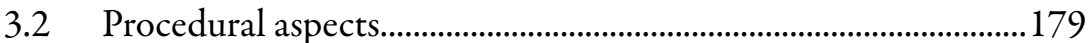

4. Referrals to the Commission pursuant to Article 22 ...............................181

4.1 Substantive criteria .............................................................................. 182

4.2 Procedural aspects...........................................................................184

4.3 Scope of the Commission's jurisdiction ..........................................186

4.4 Call upon Member States to act, Article 22(5) ..............................188

5. Pre-notification referrals to the Commission according to

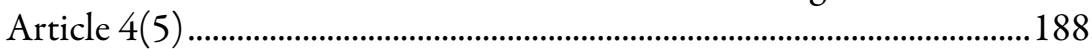

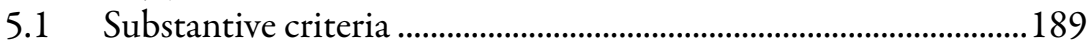

5.2 Procedural aspects...........................................................................190

\section{Chapter 6}

Remaining competences of the Member States

1. Protection of legitimate national interests under Article 21(4) ............195

1.1 General principles underlying Article 21(4) .................................196

1.2 Per se legitimate interests.................................................................197

1.3 Other types of public interests......................................................199

1.4 Procedure and sanctions................................................................200

2. Mergers in the defence sector .....................................................................202

\section{PART 3}

DEFINITION OF THE RELEVANT MARKET .............................207

\section{Chapter 1}

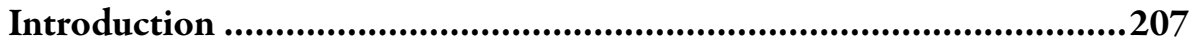

1. The objective of market definition ..........................................................207

2. Practical principles....................................................................................208

3. Source of guidance .....................................................................................209

4. Basic concepts .........................................................................................212

4.1 Competitive constraints ...............................................................212

4.2 A framework for analysis: the hypothetical monopolist test.....213

4.3 Demand-side substitution.............................................................217

4.4 Supply-side substitution ...............................................................218

4.5 Price discrimination ......................................................................222 


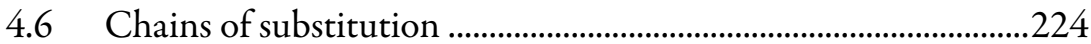

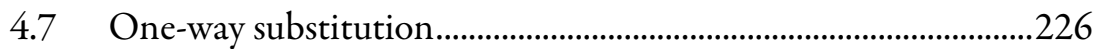

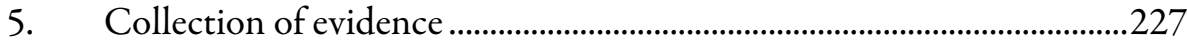

\section{Chapter 2}

Relevant product market ........................................................................231

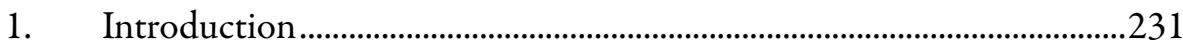

2. Assessing demand-side substitution ...........................................................232

$2.1 \quad$ Indirect evidence..............................................................................233

2.1.1 Functional substitutability: factors taken into account in determining demand-side substitutability.................................................................23

2.1.2 Product characteristics/end-use.....................................234

2.1.3 Industry product classifications ......................................236

2.1.4 Consumer preferences .....................................................237

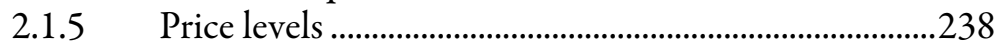

2.2 Direct evidence of substitutability: historical switching.............241

2.2.1 Natural experiments: launch of new products.............241

2.2.2 Shock analysis ...................................................................2242

2.3 Direct evidence of substitutability: prices/quantitative

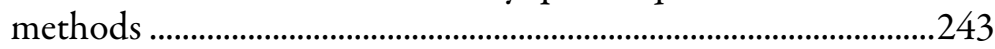

2.3.1 Own price elasticity of demand ......................................243

2.3.2 Cross-price elasticity ........................................................245

2.3.3 Critical loss/critical elasticity analysis ............................246

2.3.4 Stationarity analysis........................................................251

2.4 Switching costs and other barriers to switching ...........................252

2.4.1 Commercial barriers...........................................................253

2.4.2 Legal barriers and other barriers to switching..............254

2.4.3 Timing...............................................................................25

2.5 Price discrimination .......................................................................25

2.5.1 Different categories of customers ..................................256

2.5.2 Different distribution channels and customer

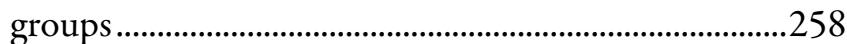

3. Assessing supply-side substitution ............................................................261

$3.1 \quad$ No significant costs...........................................................................264

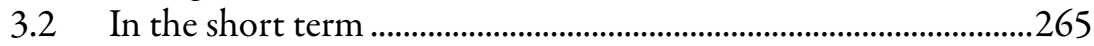

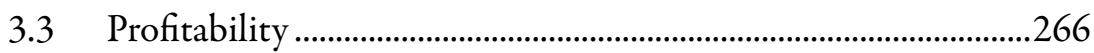

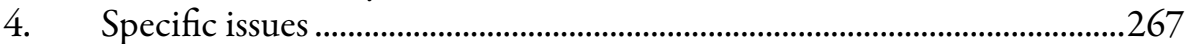

4.1 Chains of substitution .................................................................267 
4.1.1 Overlapping end-use ........................................................268

4.1.2 Continuum of end-use...............................................269

4.2 Cluster markets ............................................................................2.

4.3 Differentiated products ..................................................................271

4.4 Private labels versus branded goods ...............................................273

4.5 Merchant markets and captive sales ...............................................2.275

4.6 Aftermarkets................................................................................2.

4.7 Technology and innovation markets ...............................................279

4.8 Emerging markets ...........................................................................282

4.9 Two-sided and multi-sided markets (platforms)...........................284

4.10 Data markets ....................................................................................28

5. Conclusions on product market definition ..............................................28

\section{Chapter 3}

Relevant geographic market ...............................................................289

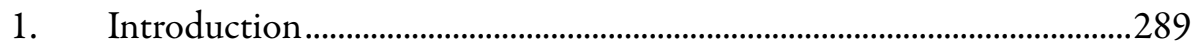

2. Assessing demand-side substitution ...........................................................290

2.1 Current market structure ..............................................................290

2.1.1 Current geographic pattern of purchases .....................291

2.1.2 Trade flows ......................................................................292

2.1.3 Similarity of market shares ............................................294

$2.2 \quad$ Prices.............................................................................................295

2.2.1 Price differences............................................................296

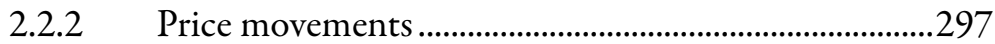

2.3 Transport costs .............................................................................300

2.4 Demand-side barriers to switching ................................................301

2.4.1 Consumer preferences ......................................................302

2.4.2 Need for proximity..............................................................303

2.4.3 National procurement policies..........................................304

3. Assessing supply-side substitution ...............................................................305

3.1 Regulatory barriers ........................................................................306

$3.2 \quad$ Adaptation cost ................................................................................306

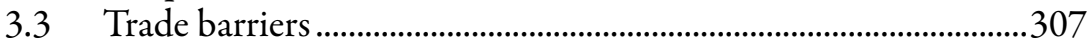

3.4 Critical loss analysis..........................................................................307

3.5 Natural experiments .........................................................................307

4. Specific Issues ............................................................................................308

4.1 European market integration .........................................................308

4.2 Chains of substitution ....................................................................3

5. Conclusions on geographic market definition ...........................................312 
PART 4

THE SUBSTANTIVE ASSESSMENT OF MERGERS

\section{Chapter 1}

Introduction

Introduction

1. The relevant counterfactual and the notion of causation .........................314

2. Horizontal, vertical and conglomerate mergers .......................................322

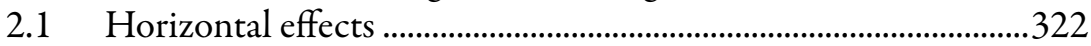

$2.2 \quad$ Vertical effects...................................................................................323

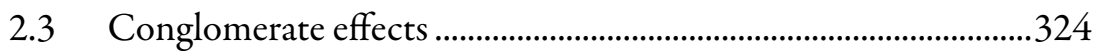

2.4 Relative prominence of the different types of effects ....................324

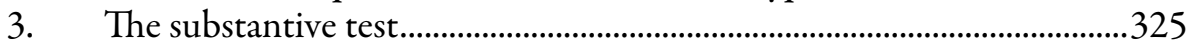

3.1 The dominance test in merger control before 2004 ......................329

3.2 The significant impediment to effective competition

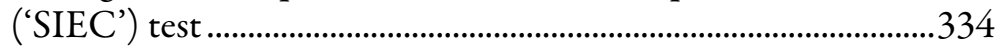

3.2.1 The removal of legal uncertainty as to the scope of the dominance test.........................................................334

3.2.2 Implications of the introduction of the significant impediment to effective competition test......................336

3.2.2.1 Dominance remains a relevant form of significant impediment to effective competition.

3.2.2.2 The application of the new substantive test: intervention rate and cases of non-coordinated effects in oligopolistic markets

3.3 Factors relevant to the competitive assessment ..............................344

3.3.1 Overview of the relevant criteria .....................................344

3.3.1.1 Criteria referred to in Article 2(1) of the Merger Regulation .................................344

3.3.1.2 Consistency with other provisions of EU Law

3.3.1.3 Time periods considered in the Commission's assessment .................................348

3.3.2 Standard of proof ............................................................350

4. Substantial part of the internal market ……………………………….......354

$4.1 \quad$ Sub-national markets ........................................................................355 
4.1.1 Economic importance of the area concerned ..............355

4.1.1.1 General geographical factors..........................358

4.1.1.2 Aggregation of contiguous local markets

4.1.1.3 Aggregation of local markets subject to the same economic strategy determined at a national level

4.2 National markets

\section{Chapter 2}

Anticompetitive effects.

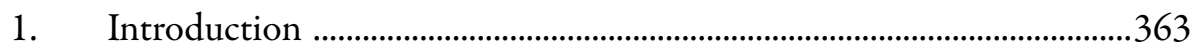

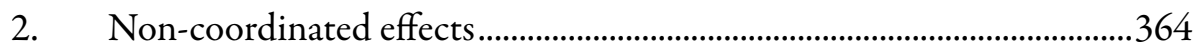

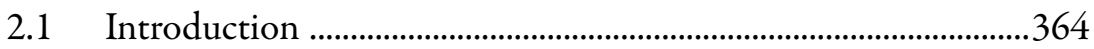

2.2 Coordinated versus non-coordinated effects.................................365

2.3 Horizontal effects .............................................................................366

2.3.1 Cournot competition (firms set volume, market decides price) ..................................................................366

2.3.2 Bertrand competition (firms set prices, market

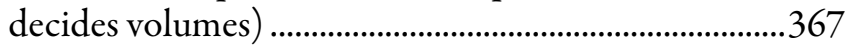

2.3.3 Market shares ...................................................................368

2.3.3.1 Presumptions and indications.......................370

2.3.3.2 Safe harbour and HHI levels...........................373

2.3.3.3 Relevance of the gap with competitors .......375

2.3.3.4 Evolution of market shares..............................377

2.3.3.5 Merger with a recent entrant..........................378

2.3.4 Other relevant factors .......................................................379

2.3.4.1 Closeness of substitution.................................379

2.3.4.2 Assessment of the competitive position of rivals ('repositioning') ..................................383

2.3.4.3 Switching cost and dual/multi sourcing ....384

2.3.4.4 Competitors' ability and incentive to increase supply ...................................................386

2.3.4.5 Ability of merged entity to hinder expansion by competitors ...............................390

2.3.5 Use of economic modelling and econometric techniques..............................................................................391

2.3.6 Special cases.......................................................................399

2.3.6.1 Minority shareholdings in competitors .....399 
2.3.6.2 Mergers leading to less innovation 404

2.3.6.3 Mergers creating/strengthening market power vis-à-vis suppliers

2.3.6.4 Mergers with a significant potential competitor

2.3.7 Mergers involving digital markets 426

2.3.8 Merger creating/strengthening a third party's (dominant) position

2.4.1.1 Forms of vertical effects

2.4.1.2 Economic approach towards vertical mergers

4.2.1.3 Illustration of the different concerns that can arise in vertical cases

2.4.2 Restricted access to supplies ('input foreclosure')......438

2.4.2.1 Ability to restrict competitors' access to inputs

2.4.2.2 Incentives to restrict competitors' access to inputs

2.4.2.3 Foreseeable effects on competition

2.4.3 Restricted access to markets ('customer foreclosure')

2.4.3.1 Ability and incentives to restrict competitors' access to customers

2.4.3.2 Foreseeable effects on competition ...............464

2.4.4 Access to information ..........................................................4 464

2.5 Conglomerate effects .....................................................................468

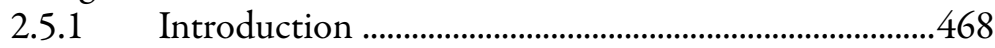

2.5.1.1 Notion of conglomerate merger ....................468

2.5.1.2 Forms of conglomerate effects ......................470

2.5.2 Conglomerate effects resulting from leveraging strategies.

2.5.2.1 Forms of leveraging 475

2.5.2.2 Analytical framework set out by the EU Courts with respect to conglomerate effects resulting from leveraging

2.5.2.3 Ability and incentive to leverage

2.5.2.4 Foreseeable effects on competition 495

2.5.3 Conglomerate effects resulting from portfolio 
(or range) effects 501

2.5.3.1 Notion of 'portfolio effect'

2.5.3.2 Example of the Commission's decisional practice

2.5.3.3 Relevant factors .................................................505

2.5.3.4 Foreseeable effects on competition ..............508

3. Coordinated effects

3.1 Introduction .509

3.2 Coordination amongst oligopolists ..............................................511

3.2.1 Introduction ...................................................................511

3.2.1.1 Notion of collective dominance ...................512

3.2.1.2 The conditions set out in Airtours ..............519

3.2.2 General pre-requisite: reaching terms of coordination

3.2.2.1 Forms of coordination ....................................523

3.2.2.2 Market structure (including number of players)

3.2.2.3 Market characteristics ...................................530

3.2.3 Specific conditions...........................................................538

3.2.3.1 Transparency (monitoring deviations).......538

3.2.3.2 Sustainability (deterrent mechanisms).......540

3.2.3.3 Stability (absence of external constraints) .543

3.2.4 Illustration of the Commission approach ....................544

3.2.5 Coordinated effects resulting from vertical and conglomerate mergers

3.3 Coordination through joint ventures amongst parent companies ('spill-over effects')

3.3.1 Introduction

3.3.1.1 Evolution of the Merger Regulation on joint ventures from 1989 to 1997

3.3.1.2 Specific additional test applied to fullfunction joint ventures: 'coordinated' effects between parent companies examined under Article 101 TFEU

3.3.2 Likelihood of coordination

3.3.2.1 Coordination between parent companies 555

3.3.2.2 Coordination on JV's market, upstream/downstream markets or on neighbouring (product or geographic) 


\section{markets \\ 3.3.2.3 Causality between creation of JV and coordination (direct consequence)

3.3.3 Appreciable restriction of competition (elimination of competition)

3.3.4 Applicability of Article 101 TFEU...............................560

3.3.4.1 Article 101(1) TFEU.......................................560

3.3.4.2 Article 101(3) TFEU......................................560

3.3.5 Consequences of the assessment under Article 2(4).561

\section{Chapter 3}

Countervailing factors

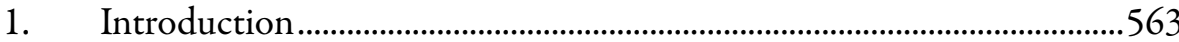

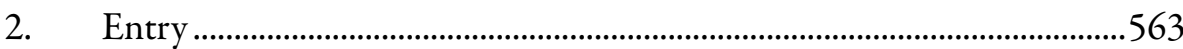

2.1 Likelihood of entry........................................................................565

2.1.1 Barriers to entry...............................................................566

2.1.1.1 Legal barriers to entry .....................................567

2.1.1.2 Technical barriers to entry ……………….....569

2.1.1.3 Other barriers to entry....................................571

2.1.2 Profitability of entry........................................................574

2.1.2.1 Costs of entry...................................................575

2.1.2.2 Market features (growing v. declining markets) (............................................................577

2.1.2.3 History of entry..............................................578

2.2 Timeliness of entry .........................................................................579

2.3 Sufficiency of entry …………………………………………........584

3. Buyer Power ………………………………………………………….....58

3.1 Notion of buyer power......................................................................586

3.2 Forms of buyer power ……………………………………….......58

3.2.1 Credibility of recourse to alternative sources...............589

3.2.2 Sponsoring expansion or entry........................................593

3.2.3 Vertical integration...........................................................59

3.2.4 Refusal to buy other products ........................................59

3.2.5 Delay purchases..................................................................60

3.3 Incentives to exercise buyer power, exclusivity and universality ........................................................................................601

3.4 Measuring buyer power ....................................................................602

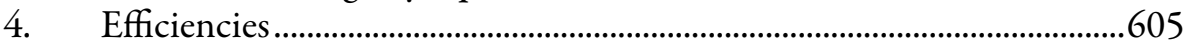

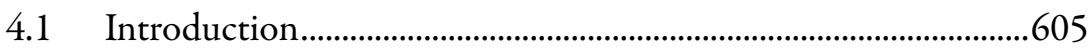


4.1.1 Legal basis...........................................................................605

4.2 Early Commission practice................................................................606

4.2.1 Initial examples ................................................................606

4.2.2 Was there ever an efficiency offence?............................608

4.3 Efficiencies under the 2004 Merger Regulation ............................611

4.4 Examples of positive treatment of efficiencies ..............................612

4.5 Approach to efficiencies in the Merger Guidelines........................615

4.6 Principles for taking efficiencies into account.................................616

4.6.1 Benefit to consumers.......................................................617

4.6.2 Pass on to customers......................................................618

4.6.3 Merger specificity...........................................................621

4.6.4 Verifiability........................................................................623

4.7 Efficiencies: overall competitive appraisal v. quantification of restrictive effects

5. Failing firm defence .........................................................................627

5.1 General pre-condition: lack of causation.......................................627

5.2 The failing division ............................................................................632

5.3 Specific criteria considered in practice ..........................................635

5.3.1 Failing firm forced out of the market............................635

5.3.2 No less anticompetitive merger.......................................637

5.3.3 Exit of assets ......................................................................638

5.4 Related questions of causation ........................................................640

\section{PART 5}

ANCILLARY RESTRAINTS.

\section{Chapter 1}

Ancillary Restraints

1. Introduction.

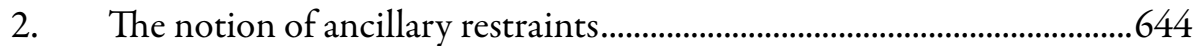

$2.1 \quad$ Restriction of competition...............................................................644

2.2 Not an integral part of the concentration.......................................645

2.3 Directly related to the concentration and necessary for its implementation

2.3.1 Directly related to the concentration .646

2.3.2 Necessary for implementing the concentration 
3. The legal status of ancillary restraints

4. The examination of the ancillary nature of restraints in merger decisions

4.1 The Commission's initial practice and the change brought by the 2001 Notice

4.2 The Lagardère judgment.

4.3 The new Merger and Implementing Regulations, the 2005

Notice and beyond

5. The most common ancillary restraints

5.1 Non-competition clauses.................................................................661

5.1.1 Acquisition of an undertaking (or parts thereof)......661

5.1.2 Creation of a joint venture.

5.2 Non-solicitation and confidentiality clauses..................................664

5.3 Licensing agreements .....................................................................665

5.3.1 Acquisition of an undertaking (or parts thereof) .......665

5.3.2 Creation of a joint venture.................................................666

5.4 Purchase/supply obligations and distribution agreements .........667

5.4.1 Acquisition of an undertaking (or parts thereof)......667

5.4.2 Creation of a joint venture...............................................668

\section{PART 6}

PROCEDURE .669

\section{Chapter 1}

Introduction

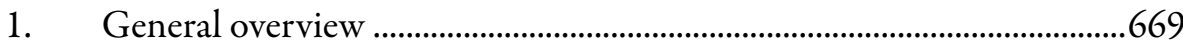

1.1 Preventive control system...............................................................670

1.2 Administrative procedure .............................................................670

1.3 Two-phase procedure........................................................................672

1.4 Obligation to issue a formal decision within a legally

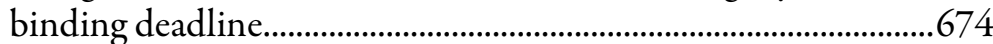

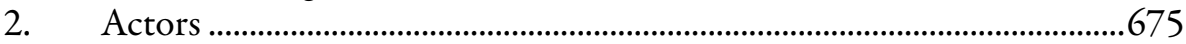

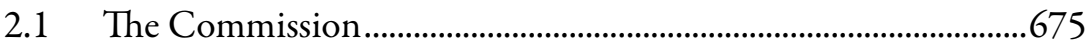

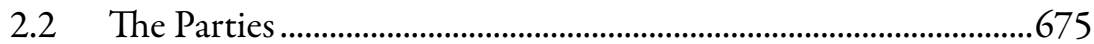

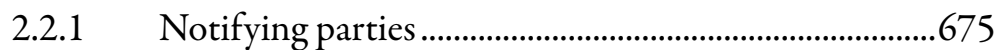

2.2.2 Other involved parties ......................................................676

2.2.3 Third parties........................................................................676 
2.3 The Member States .....................................................................677

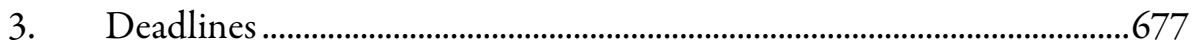

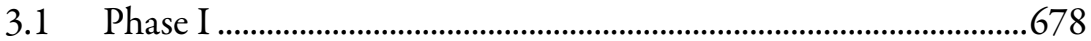

3.2 Phase II....................................................................................679

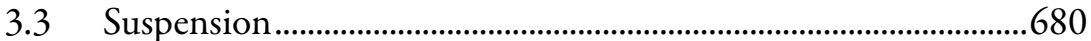

3.4 Start of deadlines after the decision has been annulled by the Court.......................................................................................682

3.5 Instances where no deadline is running............................................683

\section{Chapter 2}

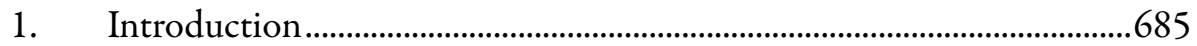

2. Pre-notification contacts ..............................................................................686

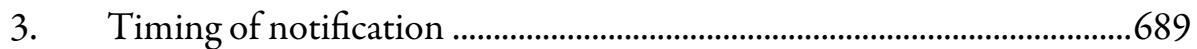

4. Formalities of notification.......................................................................690

5. Completeness of the notification ............................................................69

6. The suspension obligation.......................................................................695
6.1 The rule
6.2 The exception
6.3 The possibility of derogation

\section{Chapter 3}

Fact finding and investigation.............................................................703

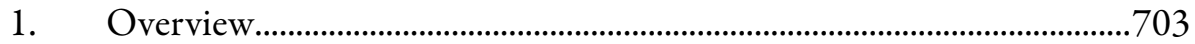

2. Powers of investigation ..............................................................................704

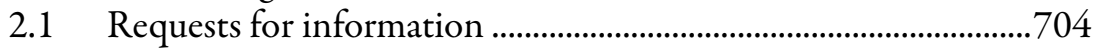

2.2 Interview........................................................................................

2.3 Inspections ……………………………………………………...707

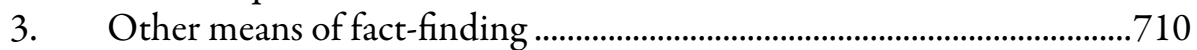

3.1 Meetings with parties and third parties .........................................710

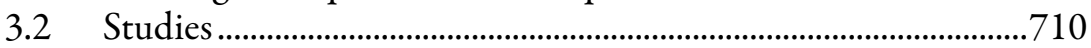

4. Liaison with Member States' authorities...................................................711

\section{Chapter 4}

Phase I proceedings...................................................................................713

1. The Phase I procedure ...............................................................................

1.1 Overview ....................................................................................... 
1.2 The serious doubts test.......................................................................715

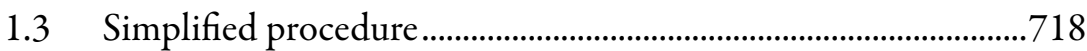

2. Types of Phase I decisions .........................................................................722

2.1 Article 6(1)(a) decision: inapplicability of the Merger Regulation ....................................................................................... 722

2.2 Article 6(1)(b) decision: non-opposition......................................724

2.3 Article 6(1)(c) decision: opening of proceedings .........................725

\section{Chapter 5}

Phase II proceedings

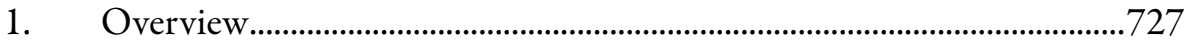

2. In-depth investigation ................................................................................

3. Rights of defence and to be heard............................................................730

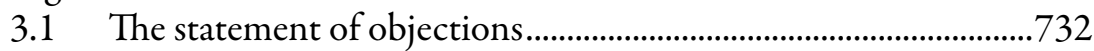

3.2 Access to the file ................................................................................

3.3 The formal oral hearing ...................................................................738

$3.4 \quad$ Hearing of third parties ...................................................................741

4. Post-hearing procedure .................................................................................742

5. Consultation of the Advisory Committee ..................................................742

6. The decision of the College of Commissioners .........................................744

7. Types of final Phase II decisions..................................................................

7.1 Article 8(1) decision: unconditional clearance ..............................745

7.2 Article 8(2) decision: clearance after modification .......................745

7.3 Article 8(3) decision: prohibition..................................................747

\section{Chapter 6}

Special procedures..................................................................................749

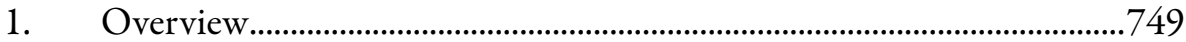

2. Dissolution orders and other measures restoring the ex ante situation ...................................................................................................

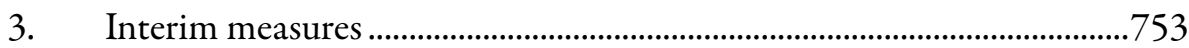

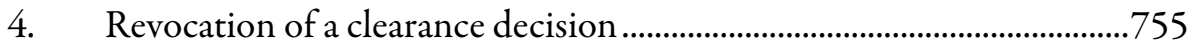

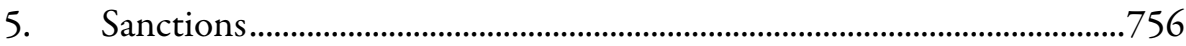

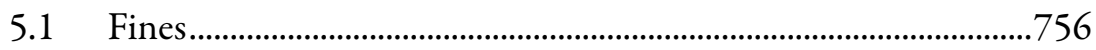

5.2 Periodic penalty payments ............................................................757 


\section{Chapter 7}

Notification and publication of decisions

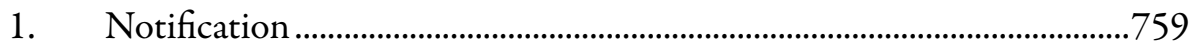

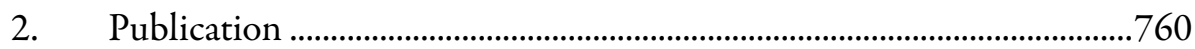

\section{PART 7}

REMEDIES

\section{Chapter 1}

Introduction

1. The importance of remedies in EU merger control

1.1 Merger control's most frequently used tool to protect competition

1.2 Remedies consume significant resources and have important economic consequences.

2. Recent debate and controversy surrounding remedies

2.1 Are merger remedies effective?

2.2 The structural vs. behavioural debate.

2.3 The call for ex post assessments of remedies

\section{Chapter 2}

Legal framework and criteria for assessing remedies

1. Terminology: 'remedies', 'commitments', 'conditions and obligations'

2. Legal framework.......................................................................................776

2.1 Remedies in Phase II .........................................................................776

2.2 Remedies in Phase I and the requirement of 'clear-cut'

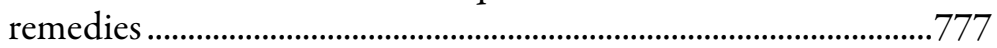

3. Basic criteria for assessing remedies.......................................................778

3.1 The remedy must entirely eliminate the competition problem ...778

3.2 The remedy must be proportionate..................................................779

3.3 The remedy must be capable of being implemented in a short period of time

4. The burden to submit remedies is on the parties but the burden of proof is on the Commission 


\section{Chapter 3}

Designing the remedy

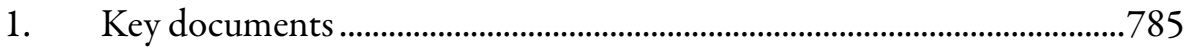

2. Practical aspects of remedies discussions between the

Commission and parties.

3. Market test of proposed remedies ……………………………………......786

4. Modifying proposed remedies and the issue of 'late remedies' ...............789

\section{Chapter 4}

Types of remedies

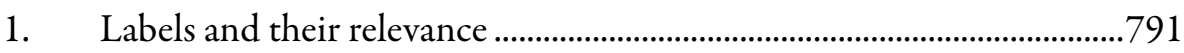

$1.1 \quad$ Structural and behavioural remedies ...............................................791

1.2 Structural remedies: only divestitures? ............................................792

1.3 All divestiture remedies include ancillary behavioural remedies

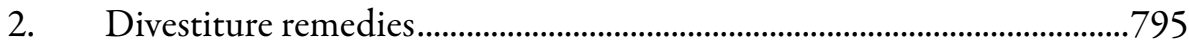

2.1 The Commission's preference for divestitures................................795

2.2 The structural vs. behavioural debate................................................799

2.3 Divestitures are preferred but not risk-free either..........................802

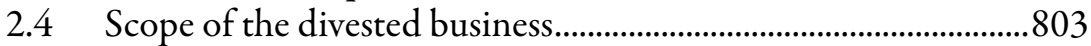

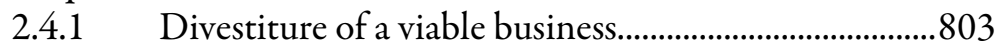

2.4.2 Divestiture of a stand-alone business..............................85

2.4.3 Carve-outs and divestitures of assets .............................807

2.5 Third party rights in relation to the divestiture..............................808

2.6 Finding a suitable purchaser of the divestiture .............................809

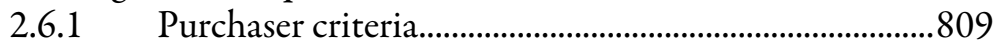

2.7 Standard arrangement, upfront buyer clause, fix-it-first remedy ....810

2.7.1 Standard arrangement ..................................................... 811

2.7.2 Upfront buyer clause ........................................................ 813

2.7.3 Fix-it-first remedy ............................................................ 814

2.7.4 Which arrangement in which case? ?...............................814

2.7.4.1 Regular vs. upfront/fix-it-first.......................815

2.7.4.2 Upfront buyer clause vs. fix-it-first ...............816

2.7.4.3 Prevalence of each type of remedy ...............818

2.7.4.4 Different terminology in the United

States. 


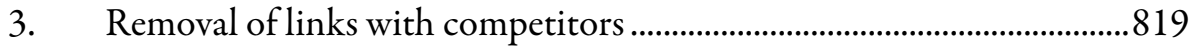

4. Access remedies .................................................................................... 821

4.1 Digital sector: interoperability remedies ......................................822

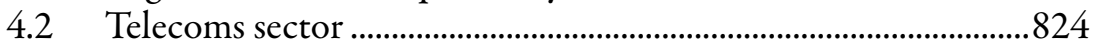

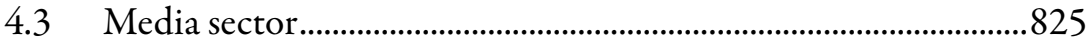

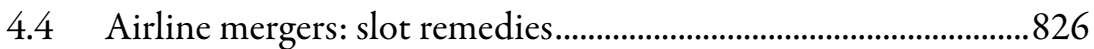

5. Other behavioural remedies.......................................................................827

\section{Chapter 5}

Implementing the remedy.......................................................................829

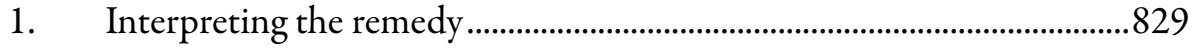

2. Appointment of a monitoring trustee .........................................................830

3. Approval of a suitable purchaser .................................................................833

3.1 The parties' search for and negotiations with a purchaser...........833

3.2 Submission of the purchaser proposal .............................................834

3.3 Assessment of the purchaser proposal .............................................835

3.3.1 Does the purchaser meet the purchaser requirements?

3.3.1.1 The purchaser must be independent from and unconnected to the parties ..........835

3.3.1.2 The purchaser's financial resources................836

3.3.1.3 The purchaser's expertise, ability and incentive

3.3.1.4 The acquisition by the purchaser should not create prima facie competition concerns nor give rise to a risk that the implementation of the commitments will be delayed

3.3.1.4.1 Prima facie competition concerns................838

3.3.1.4.2 Other regulatory concerns..............................840

3.3.2 The divestiture agreement: is the divestiture being sold in a manner consistent with the commitments? 841

3.4 The Commission's decision on the suitability of the purchaser 841

4. Duration of remedies .842

4.1 Divestiture remedies..................................................................... 842

4.2 Access and behavioural commitments...........................................843

5. Modifying the remedies.............................................................................. 844 


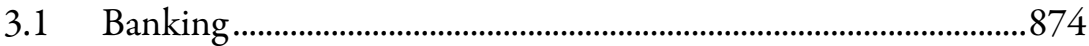

3.1.1 Retail banking services.................................................... 875

3.1.2 Corporate banking services .............................................877

3.1.3 Investment banking .......................................................... 878

3.1.4 Financial market services................................................879

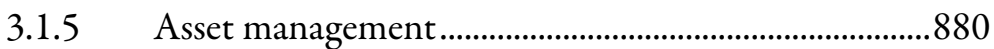

3.1.6 Private equity investment................................................882

3.1.7 Leasing .......................................................................... 883

3.1.8 Factoring ........................................................................ 883

3.1.9 Fund administration ......................................................884

3.1.10 Credit management services and debt purchasing ....885

3.2 Payment services..................................................................................886

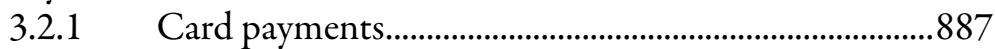

a. Card issuing........................................................88

b. $\quad$ Merchant acquiring ...........................................889

c. $\quad$ Card processing..................................................891

d. Other card-related markets .............................891

3.2.2 Account-to-account payments.........................................894

3.2.3 Mobile payments................................................................ 895

3.3 Insurance.................................................................................... 897

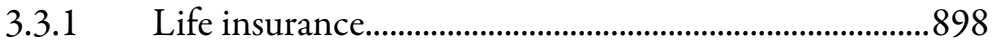

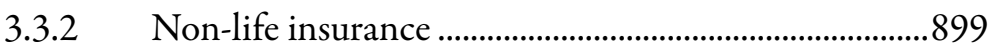

3.3.3 Reinsurance .................................................................901

3.3.4 Insurance distribution.................................................901

3.3.5 Insurance brokerage......................................................902

3.3.6 Insurance underwriting ...................................................904

3.3.7 Additional insurance-related markets ............................904

a. Third party administration claims

b. Loss adjusting services......................................905

c. Actuarial software for life insurance ............906

d. Assistance services associated with insurance products...........................................906

3.4 Financial Markets Infrastructure - stock exchange ....................907

3.4.1 Financial derivatives ......................................................908

3.4.2 Repos .............................................................................909

3.4.3 Clearing services...............................................................909

3.4.4 Post-trade services (settlement, custody and collateral management) ..................................................9910

3.5 Financial information ....................................................................912 
3.5.1 Proprietary market data ..................................................912

3.5.2 Non-proprietary market data .........................................913

3.5.3 Indices .............................................................................913

3.5.4 Datafeeds ....................................................................914

3.5.5 Desktop solutions ............................................................914

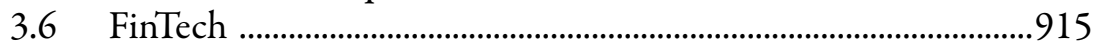

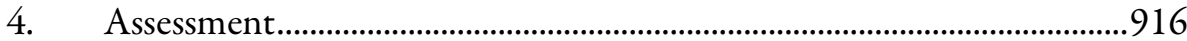

$4.1 \quad$ Banking ........................................................................................916

4.2 Payment services............................................................................919

4.3 Insurance.......................................................................................9924

4.4 Financial markets infrastructure - stock exchange.....................926

4.5 Financial information ..................................................................928

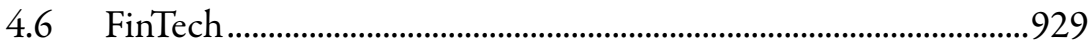

5. Remedies........................................................................................ 930

$5.1 \quad$ Banking ..................................................................................931

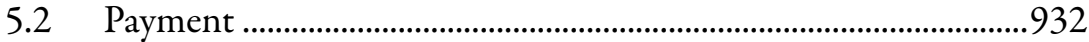

5.3 Insurance......................................................................................934

5.4 Financial markets infrastructure — stock exchange.....................936

5.5 Financial information ....................................................................936

$5.6 \quad$ FinTech ...........................................................................................937

\section{Chapter 2}

Telecommunications, media and internet services ...............................939

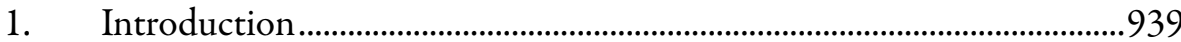

1.1 Telecommunications .....................................................................939

$1.2 \quad$ Media......................................................................................947

1.3 Internet services and platforms ……………………………….....951

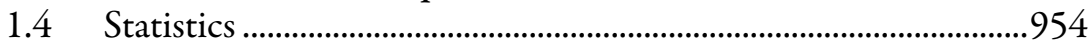

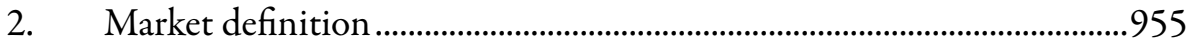

2.1 Telecommunications services ......................................................955

2.1.1 The Commission Recommendation..............................956

2.1.2 Telephony services ..........................................................960

2.1.2.1 Limited degree of substitution between fixed telephony and other types of transmission services ........................................960

2.1.2.2 Fixed telephony services.................................962

2.1.2.3 Mobile markets................................................974 
2.1.3 Other services markets.................................................982

2.1.4 Internet connectivity markets .......................................987

2.1.4.1 Access markets.................................................987

2.1.4.2 Bundles of services........................................996

2.1.4.3 Internet-based service markets.......................997

2.2 Distribution of content .......................................................... 1010

2.2.1 Online content ............................................................. 1011

2.2.2 TV .......................................................................... 1017

2.2.2.1 Retail TV ...................................................... 1017

2.2.2.2 Sale of TV advertising space....................... 1023

2.2.2.3 Wholesale supply of TV channels............. 1024

2.2.3 Cinema, sporting rights and other content.............. 1026

2.2.3.1 Films .............................................................. 1027

2.2.3.2 Other home entertainment content ........ 1030

2.2.4 Music, books, newspapers and magazines ................. 1034

2.2.4.1 Music ............................................................. 1034

2.2.4.2 Books........................................................... 1039

2.2.4.3 Newspapers and magazines ........................ 1045

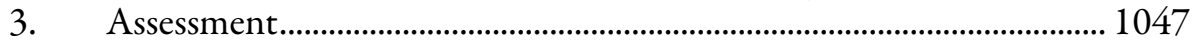

$3.1 \quad$ Introduction............................................................................... 1047

3.2 Telecommunications ..................................................................... 1047

3.2.1 Unilateral effects ....................................................... 1048

3.2.1.1 Mergers with incumbents: fixed telephony ....................................................... 1048

3.2.1.2 Leading positions ........................................... 1051

3.2.1.3 Early unilateral effects analysis................... 1052

3.2.1.4 4-to-3 or 3-to-2: mobile network operators mergers.......................................... 1053

3.2.1.5 MNOs and MVNOs ................................... 1071

3.2.1.6 Convergence mergers..................................... 1072

3.2.2 Coordinated effects ..................................................... 1075

3.2.3 Article 2(4) (................................................................. 1082

3.2.4 Vertical effects............................................................... 1083

3.2.5 Efficiencies..................................................................... 1090

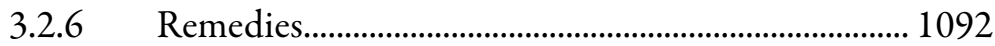

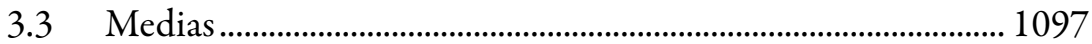

3.3.1 The pay-TV cases ......................................................... 1097

3.3.2 Book publishing: the Lagardère/Natexis/VUP case 
3.3.3 The music cases

3.4 Internet-based services and platforms

4. Conclusion

\section{ANNEX}

Telecoms and Media Merger Decisions

Conditional and Prohibition Merger Decisions.

\section{Chapter 3}

\section{Electricity and gas}

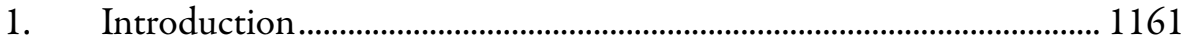

2. The relevant market ..................................................................................... 1171

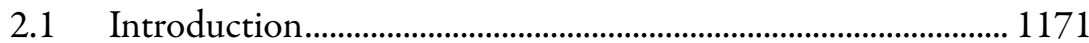

$2.2 \quad$ Electricity................................................................................. 1172

2.2.1 Electricity: relevant product market........................... 1172

2.2.2 Electricity: relevant geographic market ..................... 1185

2.3 Gas ......................................................................................... 1202

2.3.1 Relevant product market.............................................. 1202

2.3.2 Relevant geographic market ....................................... 1213

3. Substantive assessment ............................................................................. 1217

3.1 Market shares and likely existence of market power on national markets ........................................................................ 1218

3.1.1 Competitive situation in the electricity markets..... 1220

3.1.2 Competitive situation in the gas markets .................. 1231

3.2 The size and importance of competitors .................................... 1237

3.3 'Maverick' competitors ................................................................. 1239

3.4 Closeness of competition ............................................................. 1239

3.5 Commercial advantages............................................................. 1241

3.6 Horizontal / vertical integration .................................................. 1242

3.7 Economies of scale, balancing ....................................................... 1244

3.8 Advantageous generation portfolio ............................................... 1244

4. Categories of mergers and acquisitions common to the energy

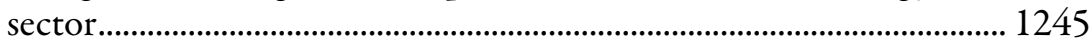

$4.1 \quad$ Horizontal mergers...................................................................... 1246

4.1.1 Acquisition of a competitor on the same relevant product and geographic market.................................. 1247

4.1.2 Acquisition of a company active on the same relevant product market but in a neighbouring relevant geographic market. 
4.2 Vertical mergers................................................................................ 1263

4.3 Conglomerate mergers ................................................................. 1274

4.4 Coordinated effects....................................................................... 1277

5. Remedies in energy cases.................................................................... 1283

$5.1 \quad$ Introduction............................................................................... 1283

5.2 Types of remedies accepted by the Commission........................ 1285

5.2.1 Divestitures .................................................................... 1285

5.2.2 Increasing the level of competition on the affected markets ......................................................................... 1288

5.2.3 Access remedies ............................................................ 1289

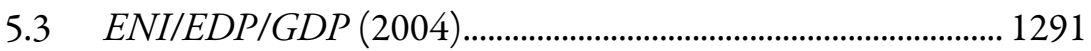

\section{Chapter 4}

Transport

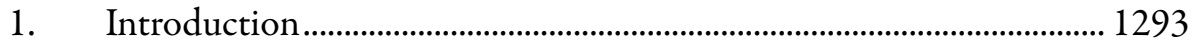

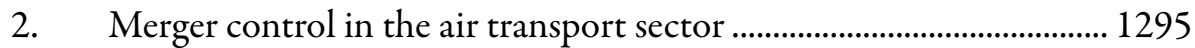

2.1 The regulatory environment ....................................................... 1296

2.2 Market definition.......................................................................... 1298

2.2.1 Demand substitution ................................................... 1299

2.2.1.1 The point of origin/point of destination approach.................................... 1299

2.2.1.2 Time sensitive and price sensitive passengers ........................................................ 1300

2.2.1.3 Direct versus indirect flights....................... 1302

2.2.1.4 Airport substitution from a passengers' perspective....................................................... 1303

2.2.1.5 Inter-modal competition............................. 1305

2.2.2 Supply substitution..................................................... 1308

2.2.2.1 Network competition .................................. 1308

2.2.2.2 Airport substitution from a suppliers' perspective........................................................ 1309

2.2.3 Cargo ............................................................................ 1310

2.3 Competitive assessment.................................................................. 1311

2.3.1 Unilateral effects ........................................................... 1313

2.3.2 Counterfactual ........................................................... 1316

2.3.3 Quantitative analysis .................................................... 1320

2.3.4 Efficiencies................................................................. 1323

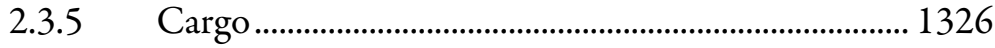

2.4 Market entry barriers...................................................................... 1326 
2.4.1 Regulatory constraints.................................................. 1326

2.4.2 Access constraints .......................................................... 1327

2.4.3 Economies of scale and scope at 'base' and 'hub' airports ............................................................................ 1329

2.4.4 Feeder traffic .................................................................. 1330

2.4.5 Other entry barriers........................................................ 1331

2.5 Remedies..................................................................................... 1333

3. Merger control in railway transport sector ............................................... 1337

3.1 The regulatory environment ........................................................ 1338

3.2 Market definition.......................................................................... 1340

3.2.1 Upstream markets ........................................................... 1340

3.2.2 Downstream markets .................................................... 1342

3.2.2.1 Freight transport ......................................... 1342

3.2.2.2 Passenger transport....................................... 1346

3.3 Competitive assessment................................................................ 1347

3.3.1 Upstream markets ......................................................... 1347

3.3.2 Downstream markets .................................................... 1348

3.3.2.1 Freight transport ........................................... 1349

3.3.2.2 Passenger transport...................................... 1354

4. Merger control in the maritime sector....................................................... 1357

4.1 The regulatory environment ....................................................... 1357

4.2 Market definition.......................................................................... 1361

4.2.1 Deep-sea liner shipping ............................................... 1361

4.2.2 Deep-sea non-liner shipping ...................................... 1364

4.2.3 Short-sea shipping ………………………………….... 1365

4.2.4 Container terminal services.......................................... 1367

4.3 Competitive assessment............................................................... 1368

4.3.1 Horizontal consolidation .............................................. 1368

4.3.1.1 Deep-sea liner shipping.............................. 1368

4.3.1.2 Deep-sea non-liner shipping ...................... 1371

4.3.1.3 Short-sea shipping ......................................... 1371

4.3.2 Vertical integration....................................................... 1372 
PART 9

JUDICIAL REVIEW

1375

Chapter 1

Introduction 1375

\section{Chapter 2}

Action for annulment.

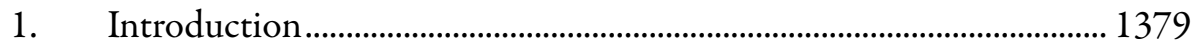

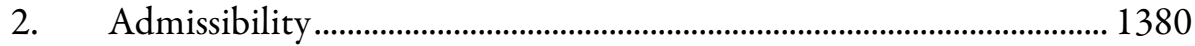

2.1 Challengeable act and locus standi ……................................... 1380

2.1.1 Key principles ............................................................... 1380

2.1.2 Final decisions on the substance of the case ............. 1382

2.1.2.1 Challengeable act......................................... 1383

2.1.2.2 Locus standi .................................................. 1390

2.1.3 Referral decisions.......................................................... 1404

2.1.3.1 Decisions on the referral of a case to a Member State................................................. 1404

2.1.3.2 Decisions on the referral of a case to the Commission............................................. 1407

2.1.4 Decisions imposing a fine or a periodic penalty payment ............................................................. 1408

2.1.5 Decisions adopted in the course of the procedure.. 1408

2.1.6 Decisions concerning commitments .......................... 1412

2.1.7 Decisions on the compatibility of national measures with Article 21 of the Merger

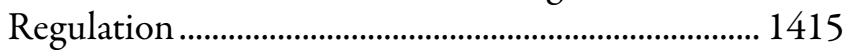

2.2 Time-limits............................................................................... 1416

2.2.1 Key principles ................................................................ 1416

2.2.2 Commission merger decisions .................................... 1417

3. Grounds for annulment and standard of review .................................. 1420

3.1 Lack of competence................................................................... 1421

3.2 Infringement of an essential procedural requirement ............... 1422

3.3 Infringement of the Treaties or of any rule of law relating to their application ......................................................................... 1424

$3.4 \quad$ Misuse of powers....................................................................... 1430

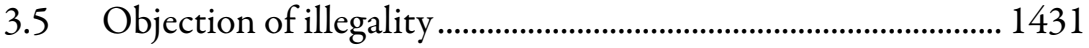

4. Intervention .............................................................................................. 1433 
4.1 Conditions for the grant of leave to intervene............................ 1433

4.1.1 Aim of the intervention............................................. 1433

4.1.2 Parties allowed to intervene .......................................... 1433

4.1.3 Time-limits and other procedural requirements..... 1440

4.2 Procedural steps following the application for leave to intervene

5. The procedure before the General Court …………………………....... 1443

5.1 Normal procedure......................................................................... 1443

5.2 Expedited procedure.................................................................... 1446

6. The annulment of a merger decision and the consequences thereof. 1449

6.1 Illegalities justifying the annulment of a merger decision....... 1449

6.2 Partial annulment ........................................................................... 1450

6.3 Consequences of the annulment of a merger decision.............. 1451

7. Interim measures ....................................................................................... 1452

7.1 Key principles ................................................................................. 1452

7.2 Assessment by the President of the General Court ................... 1454

\section{Chapter 3}

Other forms of judicial review

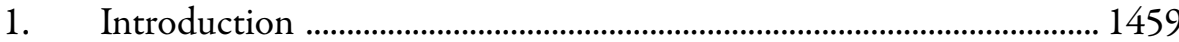

2. Actions for failure to act............................................................................ 1459

3. Actions for damages ............................................................................ 1461

3.1 Infringement of a rule of EU law intended to confer rights

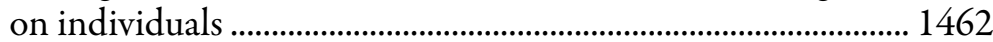

3.2 Sufficiently serious breach .............................................................. 1463

3.3 Causal link ................................................................................. 1465

4. Appeals against decisions of the General Court..................................... 1468

5. Preliminary rulings ................................................................................. 1470

6. Infringement proceedings ......................................................................... 1472 
PART 10

THE INTERNATIONAL DIMENSION 1475

Chapter 1

Introduction 1475

Chapter 2

The merger regulation and international law.

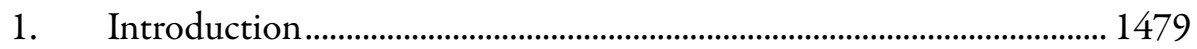

2. The territorial reach of the Merger Regulation...................................... 1481

3. The principle of non-discrimination......................................................... 1483

\section{Chapter 3}

The EEA Agreement. 1485

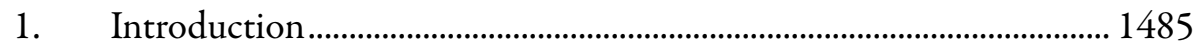

2. The legal framework for merger control.................................................. 1487

3. Cooperation under the EEA Agreement.................................................. 1488

\section{Chapter 4}

International cooperation in merger cases

1. Introduction. 1491

2. EU/US cooperation 1492

2.1 The 1991 Cooperation Agreement ............................................. 1494

2.2 Policy dialogue ........................................................................... 1498

2.3 Best Practices on Cooperation in Merger cases ........................ 1500

2.4 Administrative Arrangements on Attendance ('AAA') ............ 1504

3. Bilateral cooperation with other jurisdictions ........................................ 1505

3.1 Dedicated cooperation agreements............................................. 1506

3.2 Memoranda of Understanding ('MoUs') .................................... 1507

3.3 Cooperation provisions in bilateral trade agreements ............. 1510

4. Ad-hoc cooperation with other countries................................................. 1511

5. Recent examples of multilateral international cooperation .................. 1511

6. EU/UK cooperation following Brexit..................................................... 1513 


\section{Chapter 5}

Cooperation on merger policy and best practices

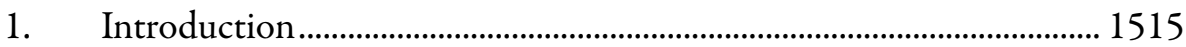

2. The Organisation for Economic Cooperation and

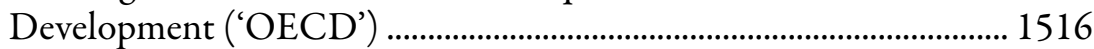

3. The International Competition Network ('ICN') ............................... 1520

4. The World Trade Organization ('WTO') .............................................. 1523

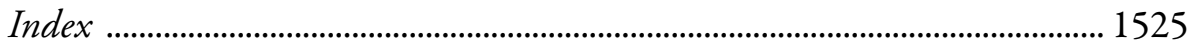




\section{Tables of Cases}

\section{CASES BEFORE THE EUROPEAN COMMISSION (BY CASE NUMBER)}

\section{Merger Cases}

\begin{tabular}{|c|c|}
\hline .10 & gra/Idea $[1991] \ldots$ \\
\hline M.12 & - Varta/Bosch [1991]........ \\
\hline 1.17 & - MBB/Aerospatiale [1991] ......................... \\
\hline I.18 & 2.259 \\
\hline .22 & - Volvo/Lex [1992] ......... \\
\hline .23 & - ICI/Tioxide $[1990]$......... \\
\hline .25 & 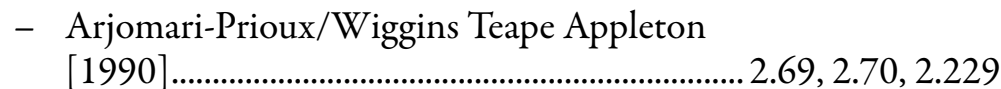 \\
\hline .42 & - Alcatel/Telettra [1991] \\
\hline 1.53 & $\begin{array}{r}\text { - Aerospatiale-Alenia/de Havilland [1991] } \ldots \ldots \ldots . .1 .6,1.26,3.111, \\
3.213,3.55,4.39,4.62,6.193\end{array}$ \\
\hline .57 & 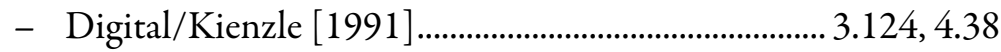 \\
\hline .58 & - Baxster/Nestl \\
\hline 1.62 & - Eridania/ISI [1991] ............... \\
\hline 1.68 & - TetraPak/Alfa-Laval [1991] ................... \\
\hline 1.82 & - Asko/Jakobs/Adia [1991] ............................................ 2.25, 2.205 \\
\hline 1.97 & 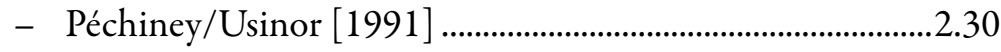 \\
\hline M.102 & $\begin{array}{l}\text { - TNT/Canada Post/DBP Postdienst/La Poste/ } \\
\text { PTT Post \& Sweden Post [1991] .......................................... } 2.179\end{array}$ \\
\hline .10 & 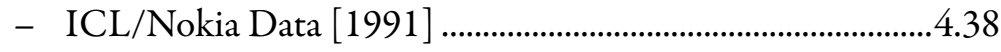 \\
\hline M.11 & 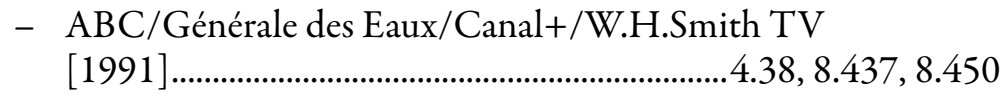 \\
\hline 113 & - Courtaulds/SNIA [1991]..... \\
\hline 116 & Express [1991] .............................................. 2.127 \\
\hline 1.126 & Lits [1992] .........................46, 2.49, 2.219, 2.238 \\
\hline 1.129 & 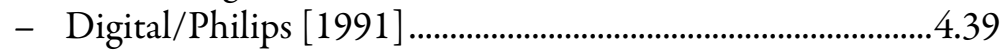 \\
\hline M.134 & - Mannesmann/Boge [1991] ............................ 3.191, 3.247, 3.312 \\
\hline M.139 & - Viag/EB Brühl [1991] ................................... \\
\hline M.156 & - Céréol/Continentale Italiana [1991]. \\
\hline
\end{tabular}




\begin{tabular}{|c|c|}
\hline M.157 & 6.234 \\
\hline & Mediobanca/Generali [1991] ......... \\
\hline & Alcatel/AEG Kabel [1991] ................................ 1.66, 2.283, 3.367 \\
\hline & Torras/Sarrió [1992]. \\
\hline & - Flachglas/Vegla [1992]... \\
\hline 33 & - Schweizer Rück/Elvira [1992].... \\
\hline 37 & - Ifint/Exor [1992].. \\
\hline & - Generali/BCHA [1992].... \\
\hline & - Nestlé/Perrier [1992]................105, 3.108, 3.119, 3.1 \\
\hline 97 & - Solvay-Laporte/Interox [1992]........ \\
\hline & 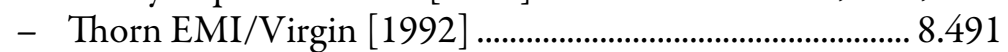 \\
\hline 6 & - Rhône-Poulenc/Snia [1992] ..... \\
\hline 3 & - Hong Kong \& Shanghai Bank/Midland [1992] ..... \\
\hline 4 & - DuPont/ICI [1992].... \\
\hline & com/SGS-Thomson [1993]....2.30 \\
\hline 5 & aine/Thyssen/Minol AG [1992] ............................. 7.284 \\
\hline 66 & 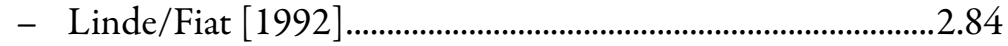 \\
\hline 8 & - CCIE/GTE [1992].. \\
\hline 9 & - British Airway/TAT [1992] .......................................... \\
\hline 1 & - Volvo/Lex (II) [1992]... \\
\hline 78 & - British Airways/Danair [1993] ............... \\
\hline 8 & 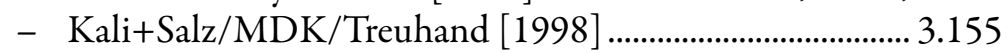 \\
\hline 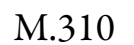 & _ Harrisons \& Crossfields/Akzo [1993]................. \\
\hline & 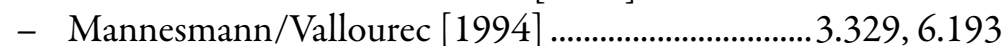 \\
\hline & bobank/Ostm \\
\hline & $83,8.87$ \\
\hline 43 & - Société Générale de Belgique/Générale de Banque \\
\hline & - JCSAT/SAJAC [1993]... \\
\hline & ecom/MCI [1993] ......... \\
\hline & - American Cyanamid/Shell [1993] .......................................3. \\
\hline & 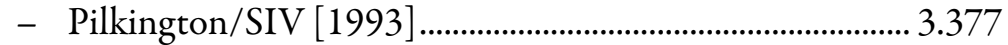 \\
\hline 366 & - Alcatel/STC [1993] ................................................... \\
\hline & 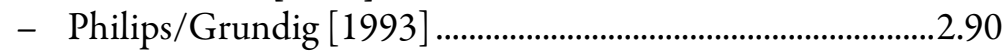 \\
\hline & 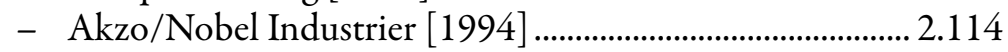 \\
\hline & 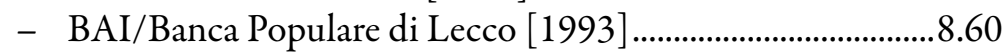 \\
\hline & _ Mannesmann/RWE/Deutsche Bank [1993] .........2.173, 2.174 \\
\hline & - CWB/Goldman Sachs/Tarkett [1994] ..... \\
\hline & - Ford/Hertz [1994] \\
\hline
\end{tabular}




\begin{tabular}{|c|c|}
\hline 9 & {$[1994]$.} \\
\hline .423 & Newspaper Publishing [1994] ... \\
\hline .425 & British Telecom/Banco Santander [1994] ... \\
\hline & - Procter \& Gamble/VP Schickedanz (II) $\left[\begin{array}{r}1994] \\
3.130,3.3 . \ldots . .36 .117\end{array}\right.$ \\
\hline .442 & - Elf Atochem/Rüttgers [1994].......................................... 2.142 \\
\hline .452 & _ Avesta (II) [1994]... \\
\hline .458 & _ Electrolux/AEG [1994] .......................... \\
\hline .460 & _ Holdercim/Cedest [1994]...... \\
\hline 469 & - MSG Media Service [1994] ........................... 2.166, 2.171, 2.173 \\
\hline 470 & Gencor/Shell [1994]... \\
\hline 475 & - Shell Chimie/Elf Atochem [1994] ... \\
\hline 477 & - Mercedes-Benz/Kässbohrer [1994]... \\
\hline .484 & - Thyssen Stahl/Krupp/Riva/Falck/Acciaiter [1994] ......... 4.161 \\
\hline 1.508 & - BHF/CCF (II) [1994] \\
\hline 1.511 & - Texaco/Norsk Hydro [1995] .................... \\
\hline 1.526 & - Sappi/DLJM/UBS/Warren [1994] ... \\
\hline .527 & - Thomson CSF/Deutsche Aerospace [1994] ……………..... 2.167 \\
\hline .528 & - British Aerospace/VSEL [1994] ........ \\
\hline 1.529 & - GEC/VSEL [1994]... \\
\hline .532 & - Cable and Wireless/Schlumberger [1994]........ \\
\hline .5 & - Union Carbide/Enichem [1995] ....... 3.305, 5.59, 5.107, 5.108 \\
\hline .551 & _ ATR/Bae [1995]........ \\
\hline 1.553 & $\begin{array}{r}\text { - RTL/Veronica/Endemol [1995] } \ldots \ldots \ldots . . .2 .88,2.93,2.302,4.38, \\
6.220,8.480,8.483,8.513\end{array}$ \\
\hline & Dalgety/The Quaker Oates Company [ \\
\hline & $\ldots 2.176$ \\
\hline 860 & $167,2.173$ \\
\hline 7 & brian Water [1995] 2.359, 2.360 \\
\hline M.574 & - Saudi Aramco/MOH [1995] ...................................2.25, 2.180 \\
\hline M.585 & 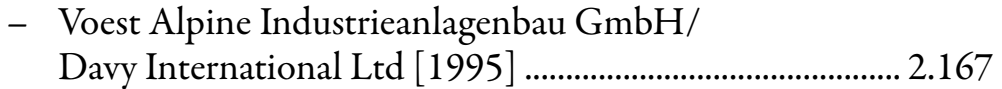 \\
\hline$f=c$ & - Ingersoll-Rand/Clark Equ \\
\hline 1.596 & - Mitsubishi Bank/Bank of Tokyo [1995] ................................... \\
\hline M.597 & - Swiss Bank Corporation/S.G. Warburg [1995] 8.36, 8.37, 8.38 \\
\hline M.601 & $\begin{array}{l}\text { - Employers Reinsurance Corp./Aachener } \\
\text { Rückversicherungsgesellschaft AG [1995]... }\end{array}$ \\
\hline & - Crown Cork \& Seal/CarnaudMetalbox [1995]...... 3.78, 3.337 \\
\hline & - RWE-DEA/Enichem Augusta [1995] ...................... 3.305, 5.78, $5.107,5.108$ \\
\hline
\end{tabular}




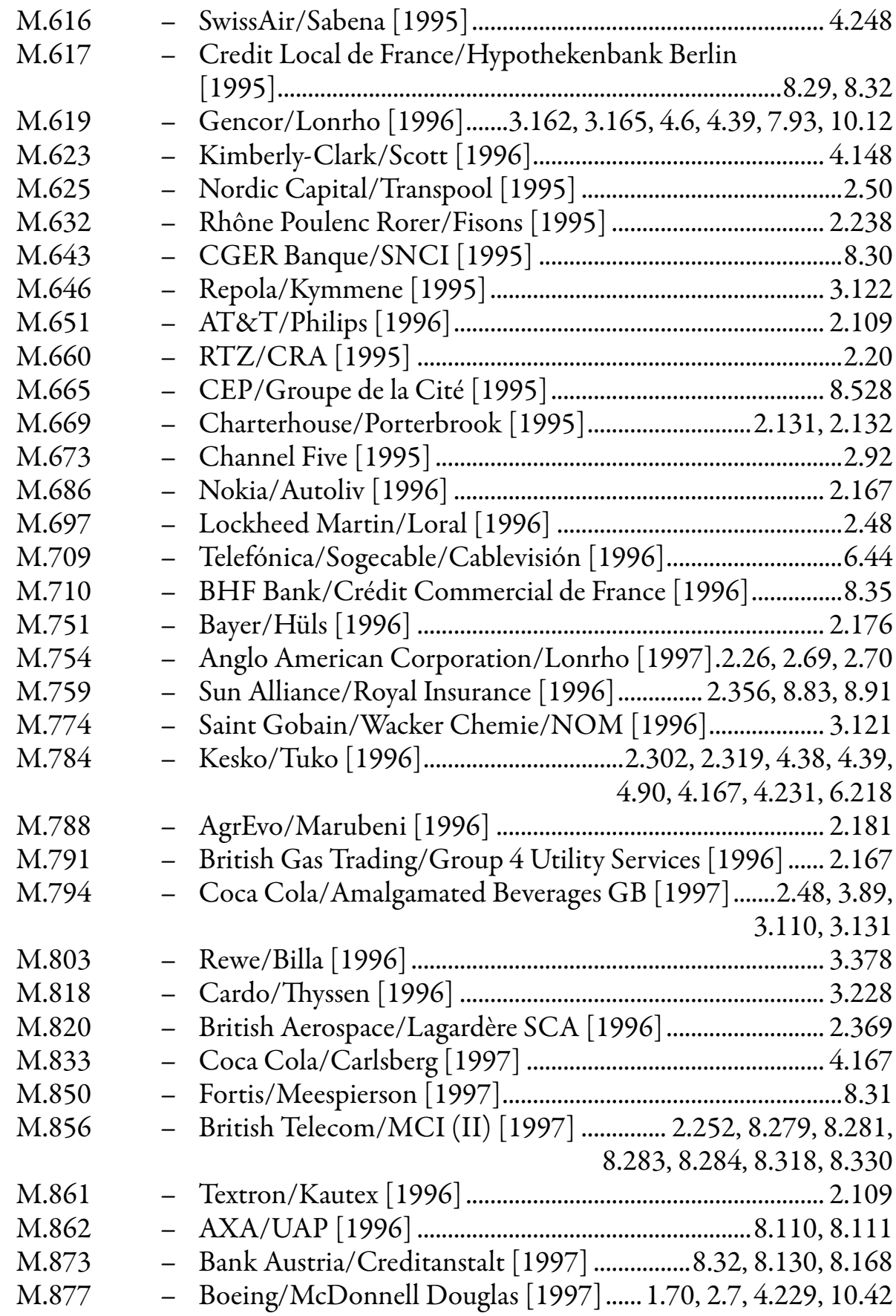




\begin{tabular}{|c|c|}
\hline 37 & - Castle Tower/TDF/Candover/Berkshire - HSCo \\
\hline .890 & - Blokker/Toys'R'Us [1997]... \\
\hline & RSB/Tenex/Fuel Logistics [1997] ..... \\
\hline .920 & Samsung/AST [1997].. \\
\hline .929 & - DIA/Veba Immobilien/Deutschbau [1997] ........................ 2.164 \\
\hline 1 & - Neste/IVO [1998] .... \\
\hline & _ UBS/Mister Minit [1997]..... \\
\hline .942 & - Veba/Degussa [1997]............... \\
\hline & - Intermarché/Spar [1997]......... \\
\hline & - Hoffmann-La Roche/Boehringer Mannheim \\
\hline 1.957 & - L'Oreal/Procasa/Cosmetique Iberica/Albesa [1997]....... 2.109 \\
\hline$[.967$ & $\ldots \ldots \ldots \ldots . . .2 .50,2.89$ \\
\hline$[.969$ & $\ldots . . . . .6 .45,6.236$ \\
\hline .970 & $-\mathrm{TK}$ \\
\hline 4 & $-\mathrm{DuP}$ \\
\hline 1 & - Prom \\
\hline 3 & - Bert \\
\hline 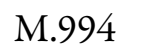 & - DuPont/Hitachi [1997]... \\
\hline & - Price Waterhouse/Coopers \& Lyb \\
\hline & - Hanr \\
\hline &. .2 .113 \\
\hline & $\ldots .8 .31,8.35,8.40,8.41$ \\
\hline & ......8.46, 8.88 \\
\hline & ......4.10 \\
\hline & ark $[1997] \ldots . . .$. \\
\hline 1.1069 & 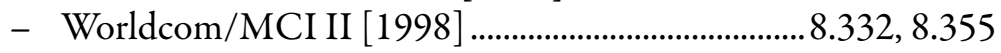 \\
\hline 75 & - Nordic Capital/Mölnlycke Clinical/Kolmi [1998]........... 3.169 \\
\hline .1080 & .................................. 4.189 \\
\hline & - Allianz/AGF [1998] ............... \\
\hline 1094 & - Caterpillar/Perkins [1998]... \\
\hline 95 & lll/PBN [1998] ... \\
\hline & Bank $[199$ \\
\hline & .....3.17, 3.210 \\
\hline & ... 3.74, 3.222 \\
\hline & 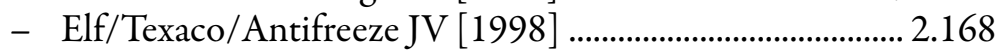 \\
\hline & - Commercial Union/General Accident, , [1998] .... \\
\hline & - ICI/Williams [1998]... \\
\hline
\end{tabular}




\begin{tabular}{|c|c|}
\hline & - Kingnisher/ wegert/Prolvarke [1998] .............................. L.11 \\
\hline & Seagram/Polygram $[1998] \ldots . . .$. \\
\hline & Rewe/Meinl [1999] ........3.75, 3.378, 4.39, 4 \\
\hline & GEC Marconi/Alenia [1998]. \\
\hline & LSG/Onex Corp/Sky Chefs/Caterair [1998] \\
\hline & - Pirelli/Siemens [1998]............... \\
\hline & Volkswagen/Rolls-Royce/Cosu \\
\hline & - Kodak/Imation [1998].... \\
\hline & - Marsh \& McLennan/Sedgwick \\
\hline & - Matra/Aérospatiale [1999] ............. \\
\hline & $47,3.325$ \\
\hline & ucas [1998]............. \\
\hline & on Electricity $[1 \mathrm{~s}$ \\
\hline & - Ford/ZF [1998] \\
\hline 77 & - Bertelsmann/Wissenschaftsverlag Springer \\
\hline & - Imetal/English \\
\hline & - Exxon/1 \\
\hline & - AT\&T/IBM Global Network \\
\hline & - San \\
\hline & .. 8.298 \\
\hline & $\begin{array}{l}6,4.258 \\
8,8.542\end{array}$ \\
\hline & $6,8.154$ \\
\hline & $6,8.527$ \\
\hline & .... 8.284 \\
\hline & 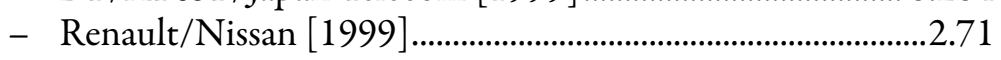 \\
\hline & t Choice [1999] ... \\
\hline & hélabo (II) [1999].. \\
\hline & Dreyfus [1999].... \\
\hline & aset $[1999]$................. \\
\hline & $25,3.230$ \\
\hline & $\mathrm{N}[1999] \ldots . . . . . .$. \\
\hline & $\ldots .8 .15$ \\
\hline & $-\mathrm{CU}$ \\
\hline & $\begin{array}{r}- \text { Tot } \\
\Gamma 20\end{array}$ \\
\hline & - Air \\
\hline & - MMS/DASA/Astrium [2000].. \\
\hline
\end{tabular}




\begin{tabular}{|c|c|}
\hline & 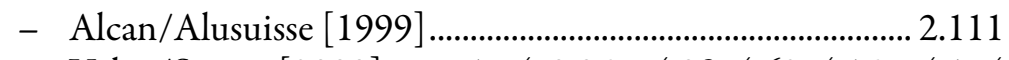 \\
\hline & - Volvo/Scania $[2000] \ldots . . . . . . .1 .74,3.357$ \\
\hline & Veba/VIAG [2000]. \\
\hline & Carrefour/Promodès [2000].. \\
\hline & Alcoa/Reynolds [2000].. \\
\hline & - Generali/INA [1999] ..............8.89, 8.146, 8.147, 8.154, 8.155, $8.177,8.182$ \\
\hline & - Alcan/Pechiney $[2000] \ldots$ \\
\hline & - BSCH/Champalimaud [1999] ... \\
\hline & $\begin{array}{r}\text { - MCI Worldcom/Sprint }[2000] \ldots \ldots . .1 .74,2.136,2 \\
2.238,2.240,6.207,8.319,8.321,8.355,8.670,\end{array}$ \\
\hline & $-\operatorname{EADS}[2000] \ldots . .$. \\
\hline & - Telekom Austria/L \\
\hline .1775 & - Ingersoll-Rand/Dressler-Rand/Inger \\
\hline & 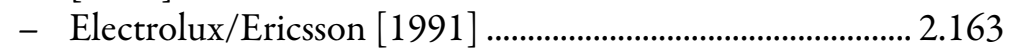 \\
\hline & h/Mannesmann [ \\
\hline 7 & - Saab/Celsius $[2000] \ldots$ \\
\hline 06 & - Astra Zeneca/Novartis [2 \\
\hline 2 & - Telefónica Terra/Amadeus [2000]... \\
\hline- & $19,8.423$ \\
\hline & _ Gla \\
\hline & .........1.74 \\
\hline & $-\mathrm{ED}$ \\
\hline & $37,8.38$ \\
\hline & $9,8.316$ \\
\hline & ... 8.328 \\
\hline & ...... 2.369 \\
\hline 82 & {$[2000] \ldots \ldots . . . . .$.} \\
\hline & 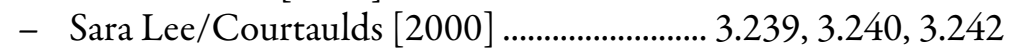 \\
\hline & - CLT-UFA/Canal+/VOX [2000]........ \\
\hline & - The Post Office/TPG/SPPL [2001]. \\
\hline & - BASF/American Cyanamid [2000] .................. \\
\hline & 1 Can $[2000] \ldots$. \\
\hline & $\mathrm{aJV}[2000]$ \\
\hline & $\ldots .8 .481,8.483$ \\
\hline & 2.182 \\
\hline & $0,8.483,8.484$ \\
\hline & UTC/Honeywell/i2/My Aircraft.com [2000]...... \\
\hline & - CDC/Banco Urquijo/JV [2000].. \\
\hline
\end{tabular}




\begin{tabular}{|c|c|}
\hline & /Renault $[2000] \ldots \ldots . .$. \\
\hline & BASF/Bayer/Hoechst/Dysta \\
\hline & Rhodia/Raisio/JV [2000]. \\
\hline & Preussag/Thompson [2000]. \\
\hline & France Télécom/Orange [2000]... \\
\hline & 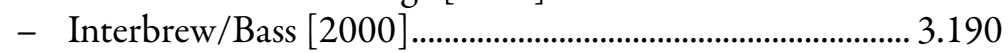 \\
\hline & Valeo/Bosch/JV [2000] .... \\
\hline & Vivendi/Canal+/Seagram [2000] ................ 3.270, 8.416, \\
\hline & Secil/Holderbank/Cimpor [2000].............. \\
\hline & h/Rexroth $[2001] \ldots$ \\
\hline & Dana/Gertrag $[2000] \ldots$. \\
\hline & $\mathrm{les} / \mathrm{JV}[20$ \\
\hline & $\mathrm{rv} / \mathrm{JV}[2000] \ldots \ldots \ldots \ldots \ldots . . . . .2 .183$ \\
\hline & issue $[2001] \ldots \ldots \ldots \ldots \ldots \ldots . . .1 .74,3.71,4.39$ \\
\hline & {$[2000] \ldots \ldots \ldots \ldots \ldots \ldots \ldots . . . . . . .3 .30$} \\
\hline & $-\mathrm{VN}$ \\
\hline & rette \\
\hline & ......................... 2.358 \\
\hline & $\ldots 2.50$ \\
\hline & - CVC/Lenzing $[2001] \ldots \ldots \ldots \ldots \ldots . . . .1 .74,3.83,3.150,3.16$ \\
\hline & $\ldots . . . .2 .166$ \\
\hline & $1] \ldots \ldots \ldots \ldots . . . . .22$ \\
\hline & - Che \\
\hline M.2211 & $-\underset{\mathrm{Uni}}{\mathrm{Stu}}$ \\
\hline M.2220 & $\begin{array}{l}\text { c/Honeywell }[2000] \ldots \ldots .1 .72,1.74,2.7,3.255 \text {, } \\
4.134,4.161,6.193,6.207,10.42,10.57,10.58\end{array}$ \\
\hline & $\ldots .40$ \\
\hline & ............4.38, 4.39 \\
\hline & $21,8.323,8.325$ \\
\hline & .....2.166, 2.183 \\
\hline & $176,2.178,3.305$ \\
\hline & ........................... \\
\hline & $\mathrm{V}[2001] \ldots$. \\
\hline M.2283 & - Schneider/Legrand [2001] .....................1.74, 4.186, 6.78, 6.193, \\
\hline & BP Chemicals/Solvay [2001 \\
\hline
\end{tabular}




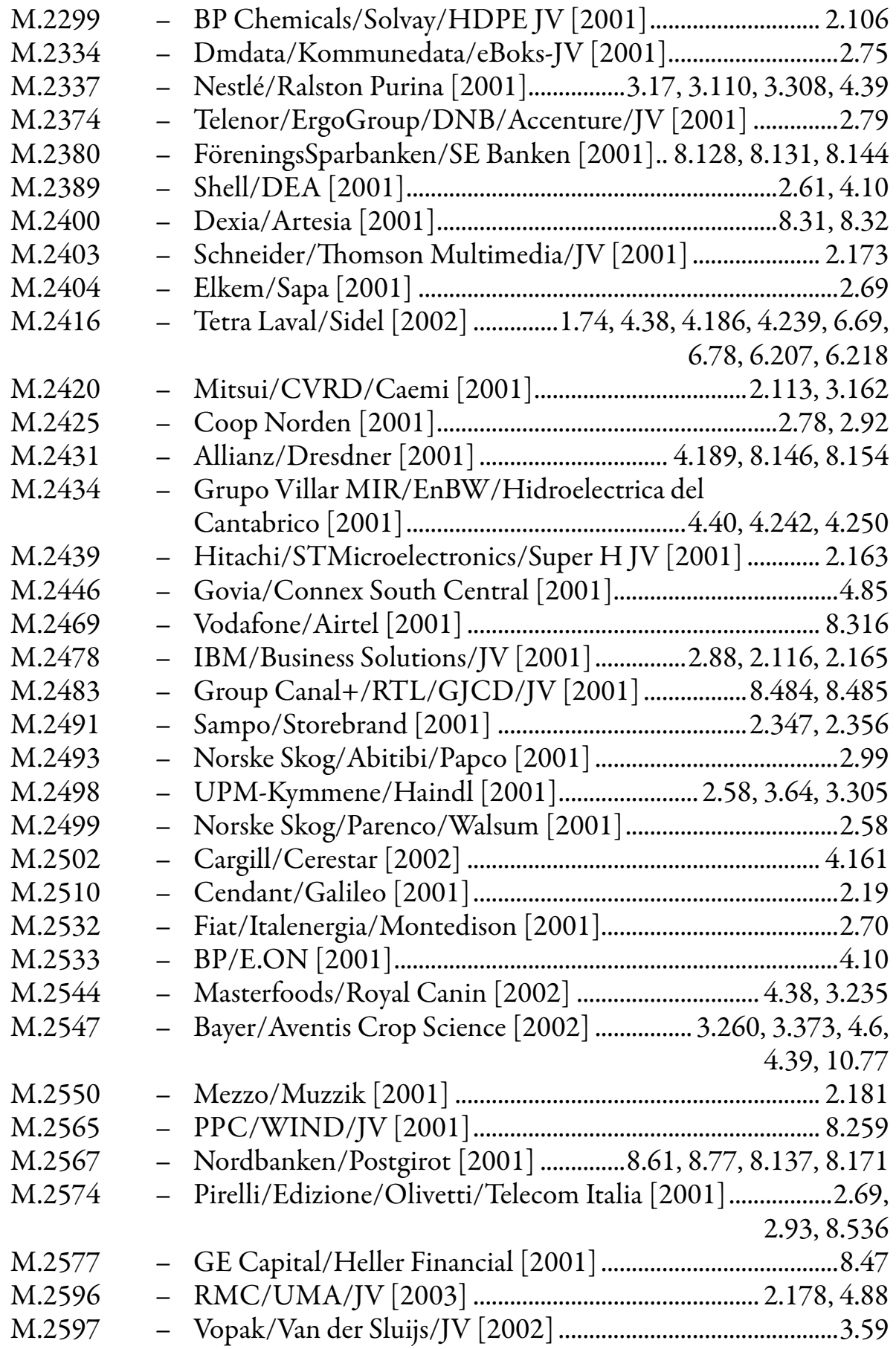




\begin{tabular}{|c|c|}
\hline & $\begin{array}{l}\mathrm{O} \\
\mathrm{C}\end{array}$ \\
\hline & INA/FAG [2001]. \\
\hline & HP/Compaq [2002].. \\
\hline & SEB/Moulinex $[2002] \ldots \ldots \ldots \ldots . . . . .$. \\
\hline & sche Bahn/ECT International/United Dep \\
\hline 26 & $\begin{array}{l}\text { - Compass/Restorama/Rail Gourmet/Gourmet Nova } \\
{[2002] \ldots \ldots \ldots \ldots \ldots \ldots}\end{array}$ \\
\hline 2640 & 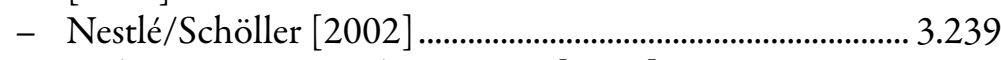 \\
\hline & - Saab/WM-Data/Saab Caran JV [2001] ................... \\
\hline & $\begin{array}{r}\text { - Haniel/Cementbouw/CVK (JV) }[2002] \ldots \ldots \ldots \ldots . .2 \\
2.111,4.6,6.44,6.45,\end{array}$ \\
\hline & - Johnson Professional Holdings/Diverseyleve \\
\hline & $\ldots . . . . . .2 .114$ \\
\hline & ..........2.19 \\
\hline & 2].... 4.40, 4.250 \\
\hline 0 & - Solvay/Mon \\
\hline & - Pro \\
\hline & - Nor \\
\hline 6 & ion/P.O Prin \\
\hline & $\begin{aligned}- & \mathrm{Ro} \\
& {[2(}\end{aligned}$ \\
\hline &. .8 .316 \\
\hline & {$[2002]$.} \\
\hline & $02] \ldots \ldots \ldots \ldots . . . . .$. \\
\hline & $02] . .8 .437$ \\
\hline & ......... 2.179 \\
\hline 30 & s $[2002] \ldots . .$. \\
\hline 1 & In/TRW [2002].................... \\
\hline & - Gaz de France/ \\
\hline 0 & $\begin{array}{r}\text { - Telia/Sonera }[2002] \ldots \ldots \ldots . . . . .8 .247,8.263,8.296,8.312,8.316 \\
8.325,8.351,8.540,8.542\end{array}$ \\
\hline 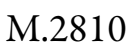 & $38,3.110$ \\
\hline & $38,3.110$ \\
\hline & .......4.38, 4.148, 4.152 \\
\hline M.28 & $\begin{array}{r}- \text { Ernst \& Young/Andersen Germany }[2002] \ldots \ldots \ldots \ldots \ldots . .2 .20,2.38, \\
2.108,2.203,3.110\end{array}$ \\
\hline & ... 8.485 \\
\hline & sa $[2002] \ldots . . . . .$. \\
\hline & - ECS/IHE [2002]. \\
\hline
\end{tabular}




\begin{tabular}{|c|c|}
\hline & Siemens/Drägerwerk/JV [2003].................... 2.179, 4.150, \\
\hline & - Linde/Sonatrach/JV [2002] ............... \\
\hline & $\begin{array}{r}\text { Newscorp/Telepiù }[2003] \ldots \ldots \ldots \ldots \ldots .3 .343,7.306,8.437,8.445 \\
8.446,8.459,8.473,8.476,8.485,8.486,8.488\end{array}$ \\
\hline .2883 & 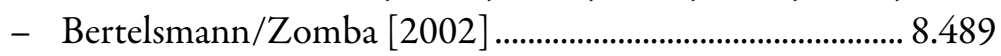 \\
\hline & Leroy Merlin/Brico [2002].... \\
\hline & lerChrysler/Deutsche Telekom/TollC \\
\hline 26 & 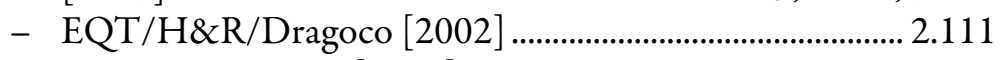 \\
\hline & NPE/MBDA/JV [2002]....... \\
\hline 02 & - Deutsche Post/Wegener/Interlanden \\
\hline & $\begin{array}{r}\text { - Lagardère/Natexis/VUP [2004] ....... } 1 . \\
4.167,4.175,4.231,6.51,6.1 \\
8.512,8.513,8 .\end{array}$ \\
\hline$[.2982$ & - Lazard/IntesaBCI/JV [2002].... \\
\hline 7 & - Accor/Ebertz/Dorint [2002].. \\
\hline 3 & - Electrabel/Energia Italiana/Inter \\
\hline & a/Semco/Prenad Totalinstallatöre N/Backlunds \\
\hline 30 & apital/DOR Chemical/ \\
\hline 5021 & - Sta \\
\hline .3035 & $\begin{array}{r}\text { - Berkshire Hathaway/Converium/Gaum/JV [2003] .........2.79, } \\
2.92,8.83,8.90,8.101\end{array}$ \\
\hline & 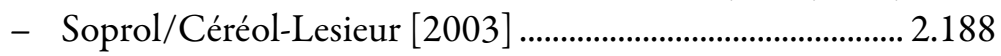 \\
\hline &. .3 .111 \\
\hline 30 & $\begin{array}{r}\text { - Celanese/Degussa/European Oxo Chemicals [2003] } \ldots . .3 .123, \\
3.124,3.198,3.247\end{array}$ \\
\hline 3 & $\begin{array}{l}\text { - Banca Intesa/Capitalia/IMI Investimenti/ } \\
\text { Unicredito Italiana/Fidis Retail Italia [2003] ........................2.90 }\end{array}$ \\
\hline 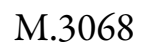 & dman Sachs/Oriville [2003] ...... 2.50, 2.113 \\
\hline 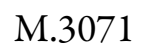 & n/P.O Princess (II) [2003] ......................2.20 \\
\hline 083 & - GE/Instrumentarium [2003] ...........4.107, 4.150, 4.152, 4.179 \\
\hline .3097 & gate IT/Global Transport Solutions JV \\
\hline & ..... 2.312 \\
\hline & airies $[2003] \ldots$ \\
\hline & - GE/EFGA NDT [2003].... \\
\hline & - CVRD/CAEMI [2003] \\
\hline
\end{tabular}




\begin{tabular}{|c|c|}
\hline & $\begin{array}{l}\text { E.ON/Fortum Burghausen/Smaland/Endenderry } \\
{[2003]}\end{array}$ \\
\hline & Bertelsmann/Springer/JV [2005] ................................ 5.11, 5.106 \\
\hline & Philip Morris/Papastratos [2003].. \\
\hline & 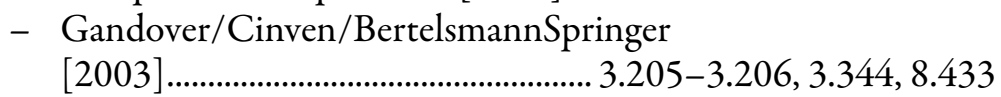 \\
\hline 1.3198 & VW/VW-Audi Vertriebszentren [2003] ......................... 2.19, 2.62 \\
\hline & \\
\hline & $02,4.179$ \\
\hline & 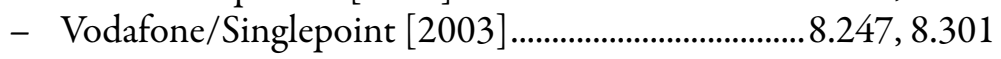 \\
\hline & del $[2004] \ldots$. \\
\hline & $\mathrm{CRH} / \mathrm{CVC} / \mathrm{Cementbou}$ \\
\hline & $\mathrm{CRH} /$ Cementbouw \\
\hline & 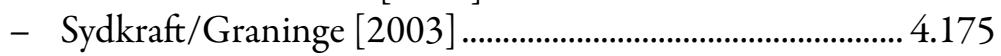 \\
\hline & - Shell España/Cepsa/SIS [2004]... \\
\hline & - Air France/KLM [2004]................. \\
\hline & $-A G$ \\
\hline & - Shell \\
\hline & - ExxonMobil/BEB [2 \\
\hline & - GE/Amersham $[200$ \\
\hline & ey/Glick/Canary Wharf [2004] ... \\
\hline & - RT \\
\hline & - Sony/BMG (4064) [2004] ...... \\
\hline & Carlsberg/Holsten $[2004] . . . . .$. \\
\hline & $\mathrm{k}[2005] \ldots$ \\
\hline & ikring [2004]. \\
\hline & asspack $[2004$ \\
\hline & e $[2004] \ldots \ldots \ldots \ldots \ldots \ldots \ldots \ldots \ldots \ldots . . . . .2 .38,2.110$ \\
\hline & 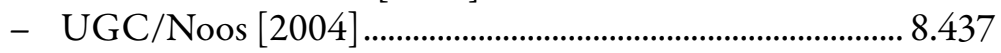 \\
\hline & $69,3.352$ \\
\hline & 2004].......3.343, 3.345, \\
\hline & $\ldots 3.305,3.191,4.161$ \\
\hline & 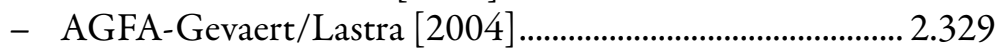 \\
\hline & - ENI/EDP/GDP [2004] ................... 2.9 \\
\hline & 420 \\
\hline & $\ldots .2 .58,2.329,3.357$ \\
\hline & - TPG/DLJ/CSFB/Grohe [2004].. \\
\hline & - BAE Systems/Alvis [2004]. \\
\hline
\end{tabular}




\begin{tabular}{|c|c|}
\hline & - \\
\hline & $\begin{array}{l}\text { - Wiener Börse et al./Budapest Stock Echange/ } \\
\text { Budapest Commodity Exchange/Keler/JV [2005] .............8.41 }\end{array}$ \\
\hline & VNU/WPP [2004].... \\
\hline & - CVC/Permira/AA [2004].. \\
\hline 534 & 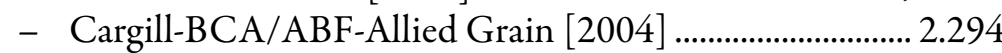 \\
\hline & 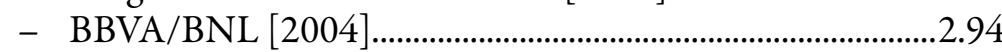 \\
\hline & PKN Orlen/Unipetrol [2005]..... \\
\hline 7 & ntander/. \\
\hline & Telekom/Eur \\
\hline & Cen \\
\hline & \\
\hline & - ThyssenKrupp/Howaldswerke- \\
\hline & 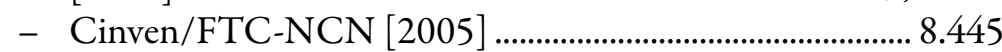 \\
\hline & $8,8.320$ \\
\hline 3649 & $\begin{aligned}- & \text { Finm } \\
& {[200}\end{aligned}$ \\
\hline$[3653$ & - Siemens/VA Tech $[2005] \ldots \ldots \ldots \ldots \ldots \ldots \ldots . . .1 .49,3.176,4.55,4.190$ \\
\hline & - Blackstone/NHP [2005] \\
\hline & - Alcatel/Finmeccanica/Alcatel Alenia Space \& Telespazio \\
\hline & $-\mathrm{Ho}$ \\
\hline & 8 \\
\hline & $-\mathrm{B} T$ \\
\hline & - E. \\
\hline & $\ldots . .8 .61$ \\
\hline 2 & - Verizon/MCI [2005] ........................2.222, $8.288,8$ \\
\hline & 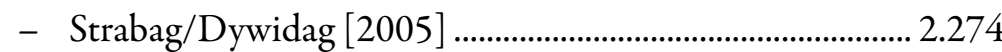 \\
\hline & comed $[2005] \ldots$ \\
\hline & .....2.25, 2.205 \\
\hline & 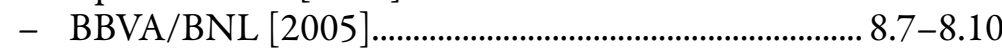 \\
\hline & a/Swiss $[2005] \ldots$ \\
\hline & $\ldots .8 .110,8.111$ \\
\hline M.3776 & - Vodafone/Oskar Mobile [2005]........ \\
\hline & 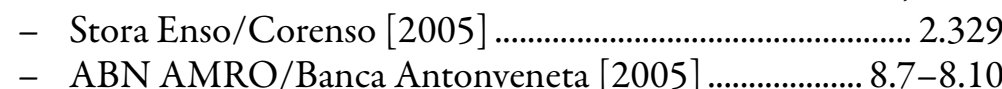 \\
\hline
\end{tabular}

xlix 


\begin{tabular}{|c|c|}
\hline & Crédit Agricole/Caisse d'Epargne \\
\hline & TPG/Apax/Tim Hellas [2005].. \\
\hline & Johnson Controls/Robert Bosch/De \\
\hline & OMYA/Huber [2005] .. \\
\hline & EADS/Nokia $[2005] \ldots . . .$. \\
\hline & Continental/Xtra Print $[2005] . . . . .$. \\
\hline & Telefónica/Cesky Telecom [2005]...... \\
\hline 38 & 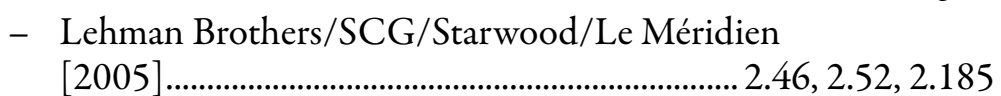 \\
\hline & - DAIG/Viterra $[2005]$ \\
\hline & $8.31,8.40,8.41,8.4$ \\
\hline & ....................2.28 \\
\hline 5 & $\begin{aligned}- & \text { Tesco } \\
& {[200}\end{aligned}$ \\
\hline 6 & $\begin{array}{r}- \text { T-Mobile Austria/Tele.Ring [2006].4 } \\
8.263,8.265,8 .\end{array}$ \\
\hline 1.3920 & - France Telecom/Amena [2005].......8.263, 8.272, 8.3 \\
\hline & - Lufthansa/Eurowings [2005] \\
\hline & $. .4 .232,4.235$ \\
\hline & - Car \\
\hline & $-\mathrm{EA}$ \\
\hline & - Gas Natural/Endesa [2005] ....................2.4, 2.237, 2.238 , \\
\hline & /Gemplus [2006]......... \\
\hline & ....................3.38 \\
\hline & .................. 2.106 \\
\hline & $\begin{array}{r}\text { - Telefónica/O2 [2006]............8.259, 8.263, 8.265, 8.296, 8.301, } \\
8.307,8.308,8.314,8.316\end{array}$ \\
\hline & $8.147,8.180$ \\
\hline & ............4.72 \\
\hline & ns [2006].. \\
\hline & IAR $[20$ \\
\hline & .......7.67 \\
\hline & $\ldots . .2 .89$ \\
\hline & .................. 2.364 \\
\hline & $\ldots 2.303,2.310$ \\
\hline & - UniCredit/HVB... \\
\hline
\end{tabular}




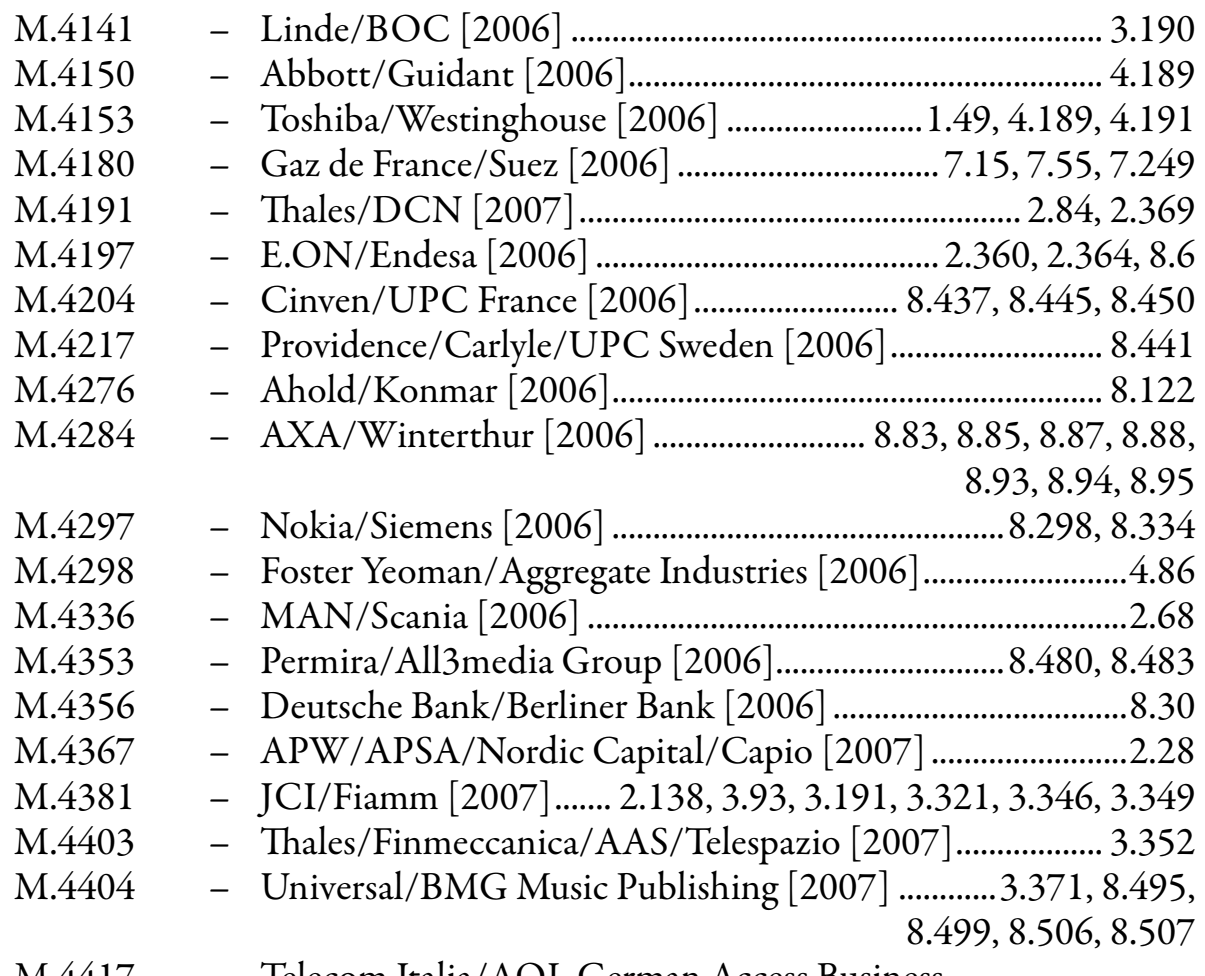

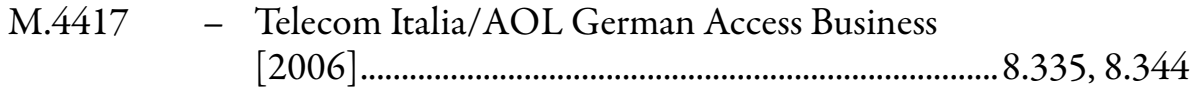

M.4439 - Ryanair/Aer Lingus [2007] ...... 2.118, 2.251, 3.92, 4.72, 4.147, $4.176,6.207,6.219,7.54,7.188$

M.4442 - Carphone Warehouse/AOL UK [2006].... 8.257, 8.317, 8.335

M.4476 - Norilsk Nickel/OMG Nickel [2007] ......................... 3.316, 5.62

M.4504 - SFR/Télé 2 France [2007]...................2.222, 8.437, 8.459, 8.474

M.4505 - Freeport-Mcmoran Copper \& Gold/Phelps Dodge Corporation [2007] .................................................... 8.457, 8.461

M.4513 - Arjowiggins/M-Real Zanders Reflex [2008]............ 3.93, 3.165,

M.4519 - Lagerdère/Sportfive [2007]

M.4521 - LGI/Telenet [2007] .................................................2.108, 3.345

M.4522 - Carrefour/Ahold Polska [2007]...............................................4.86

M.4525 - Kronospan/Constantia [2007]...................................3.334, 3.336

M.4533 - SCA/P\&G (European tissue business)

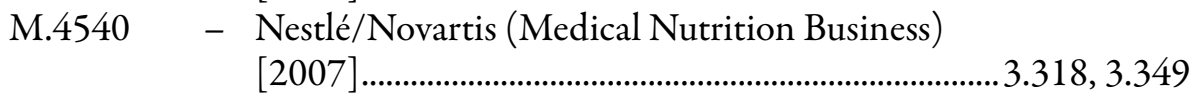




\begin{tabular}{|c|c|}
\hline & TUI/First Choice [2007] ............................................. 3.186, 4.12 \\
\hline & KarstadtQuelle/MyTravel [2007].. \\
\hline & $\begin{array}{l}\text { - Egmont/Bonnier Books } \\
{[2007] \ldots \ldots \ldots \ldots \ldots \ldots \ldots \ldots \ldots \ldots \ldots \ldots \ldots \ldots \ldots \ldots . . .2 .294,8.515,8.517,8.519,8.524}\end{array}$ \\
\hline 7 & - AEE/Lentjes [2007]..... \\
\hline & Enel/Acciona/Endesa [2007] ... \\
\hline & ance Business [2007]......8.88,, \\
\hline & enor Satellite Servic \\
\hline & C [2007]... \\
\hline & $\begin{array}{r}\text { - Thomson Corporation/Reuters Group [ } 200 \\
8.124,8\end{array}$ \\
\hline & - Google/Doubleclick [2007] .................. \\
\hline & $08] \ldots \ldots \ldots . . . .$. \\
\hline & ahn/EWS [2007]..... \\
\hline & - Norddeutsche Affinerie/Cumerio [2008] ................................200 \\
\hline & - RBS/ABN Amro Assets [2007].... \\
\hline 14 & 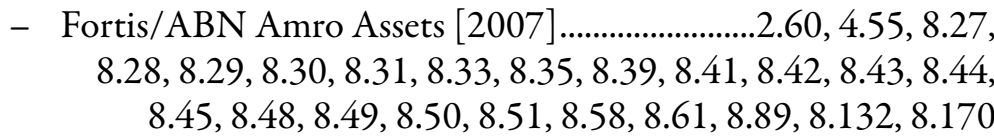 \\
\hline 5 & Santander/ \\
\hline & - Tom \\
\hline & - Cor \\
\hline & - Caly \\
\hline & - Nol \\
\hline & e2 Spai \\
\hline & - STX \\
\hline 0 & - $\mathrm{ABF} / \mathrm{GBI}$ Business [2008] ................. \\
\hline & $\ldots \ldots \ldots \ldots \ldots . . . . .2$ \\
\hline & 8] .............2.25, 2.47 \\
\hline M.4 & el/Compagnie Nationale \\
\hline & - Galp \\
\hline & - Vive \\
\hline & /Munich RE/GA \\
\hline & - Lesa \\
\hline M.50 & - Friesland Foods/Campina [2008]........ \\
\hline & \\
\hline & - Aviva/UBI Vita [20 \\
\hline
\end{tabular}


M.5075 - Vienna Insurance Group/EBV [2008]..............8.83, 8.84, 8.85, $8.86,8.87,8.88,8.146,8.148,8.177$

M.5083 - Groupama/OTP Garancia [2008].................................8.91, 8.92

M.5094 - Nokia/Trolltech [2008] ......................................................... 3.298

M.5112 - Rewe Plus/Discount [2008]......................................3.301, 3.378

M.5121 - Newscorp/Premiere [2008]................ 2.68, 2.245, 3.343, 3.345,

M.5141 - KLM/Martinair [2008]

M.5148 - Deutsche Telekom/OTE [2008].................................. 2.93, 8.278

M.5152 - Posten/Post Danmark [2009] ……………………….....3.371, 4.6

M.5153 - Arsenal/DSP [2009] ..................................................3.305, 4.123

M.5157 - Volkswagen/Scania [2008] .........................................................2.68

M.5217 - GEFA/PEMA [2008]............................................................4.

M.5241 - American Express/Fortis/Alpha Card [2008] 2.191, 8.61, 8.66

M.5250 - Porsche/Volkswagen [2008] ...........................................2.43, 2.68

M.5253 - Sanofil-Aventis/Zentiva [2009] ................................................. 3.116

M.5254 - Acea/Ondeo Italia/Acque Blu [2008] .................................. 2.2.274

M.5272 - Sony/SonyBMG [2008].............................................8.417, 8.423

M.5295 - Teva/Barr [2008] ……………………………………...... 3.116

M.5335 - Lufthansa/SN Airholding (Brussels Airlines) [2009]...... 2.251,

M.5355 - BASF/CIBA [2009] .......................................3.300, 4.55, 7.243

M.5363 - Santander/Bradford \& Bingley Assets [2008] 2.38, 2.235, 8.26

M.5364 - Iberia/Vueling/Clickair [2009] ............................................. 7.188

M.5384 - BNP Paribas/Fortis [2008] .............. 8.26 8.29, 8.30, 8.36, 8.38, $8.48,8.49,8.58,8.61,8.83,8.84,8.133,8.138,8.168,8.172$

M.5403 - Lufthansa/BMI [2009].........................................4.12, 4.14, 4.85

M.5406 - IPIC/MAN Ferrostaal [2009].................................... 1.49, 4.189

M.5421 - Panasonic/Sanyo [2009] ...........................................................6

M.5426 - Dassault Aviation/TSA/Thales [2009] ................................. 2.369

M.5432 - Crédit Mutuel/Cofidis [2009] ..................................... 2.114, 8.29

M.5440 - Lufthansa/Austrian Airlines [2009] ................. 1.100, 4.12, 4.14,

M.5450 - Kühne/HGV/TUI/Hapag-Lloyd [2009] ............................ 2.213

M.5481 - Areva SA/Areva NP [2009] ……………………………......1.116

M.5505 - Celesio/Pharmexx [2009]..................................................... 2.329

M.5508 - SoFFin/Hypo Real Estate [2009] ..................................2.32, 8.19

M.5529 - Oracle/Sun Microsystems [2010]................................ 3.224, 4.55

M.5532 - Carphone Warehouse/Tiscali UK [2009]........................................258, 8.317, 8.336, 8.342, 8.349 


\begin{tabular}{|c|c|}
\hline & 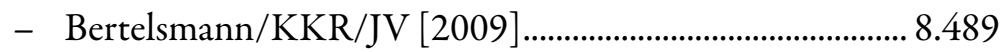 \\
\hline & egebel $[2009] .$. \\
\hline & $\begin{array}{l}\text { BlackRock/Barclays Global Investors UK Holdings } \\
\text { [2009] }\end{array}$ \\
\hline 5 & - Towers Perrin/Watson Wyatt [2009]....................... 8.107, 8.108, $8.146,8.178$ \\
\hline 1.5605 & Crédit Mutuel/Monabanq [2009]....... \\
\hline & 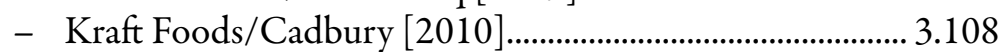 \\
\hline & - T-Mobile/Orange UK [2010] ...................... 7.289, 8. \\
\hline & SNCF/LCR/Eurostar $[2010] \ldots$. \\
\hline & $8,4.175$ \\
\hline s & - NIBC/ABN AMRO Fund/MID Ocean Group \\
\hline 1.5 & 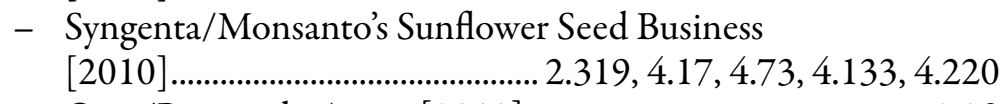 \\
\hline & - Otto/Prim \\
\hline & - Microsoft/Ya \\
\hline 15 & $\begin{array}{r}\text { - Crédit Agricole/Société Générale Asset [2 } \\
5.109,8\end{array}$ \\
\hline 1.57 & 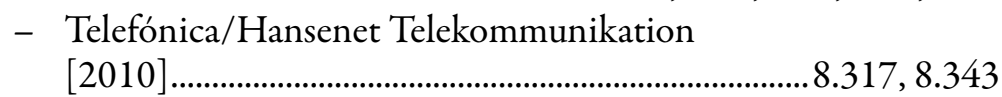 \\
\hline & .... 8.450 \\
\hline & $\ldots . . .4 .85$ \\
\hline & $6,8.468$ \\
\hline & - Lidl \\
\hline & $\operatorname{ergy}[2010] \ldots \ldots \ldots \ldots \ldots \ldots . . . .5 .62$ \\
\hline & - Erste Bank/ASK [2010] .......................................... 25, 2.47, 8.30 \\
\hline & \& Gamble/Sara Lee Air Care [2010].........2.303, 2.320 \\
\hline & ............... $3.166,7.188$ \\
\hline & nweiz Assets [2010]......... \\
\hline & $10] \ldots \ldots \ldots . . . . . .2 .150$ \\
\hline & $\begin{aligned}- & \text { Rep } \\
& {[20}\end{aligned}$ \\
\hline & - Pro \\
\hline & ..........4.14 \\
\hline & Gaviota \\
\hline & \\
\hline & - MetLife/Alico/Delam [2010]. \\
\hline
\end{tabular}




\begin{tabular}{|c|c|}
\hline & $\begin{array}{r}\text { - News Corp/BSkyB }[2010] \ldots \ldots \ldots \ldots . .2 .349,2.355,2.365,8.437 \\
8.439,8.442,8.450,8.452,8.454,8.457,8.459,8.460,8.461 \\
8.462,8.464,8.472,8.476,8.477,8.485,8.527,8.529\end{array}$ \\
\hline .5943 & - $\begin{array}{l}\text { Abu Dhabi Mar/Thyssen Krupp Marine Systems } \\
\text { [2010]............................................................... } 2 .\end{array}$ \\
\hline .5948 & 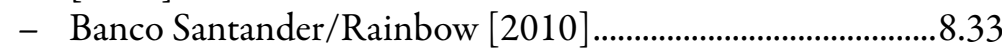 \\
\hline & $\begin{array}{l}\text { - Credit Agricole/Cassa di Risparmio della Spezia/ } \\
\text { Agences Intesa Sanpaolo [2010]...............................2.274, } 2.283\end{array}$ \\
\hline 1.5968 & - Advent/Bain Capital/RBS WorldPay [2010] ......... \\
\hline & - SC Johnson/Sara Lee insecticides [201 \\
\hline & Intel \\
\hline & $\begin{array}{r}\text { - CVC/Apollo/Brit Insurance }[2011] \ldots \ldots \ldots \ldots \ldots . .8 .83, \\
8.92,8.93,8.94,8.96,8 .\end{array}$ \\
\hline & - China National Bluestar/Elkem [2011] .... \\
\hline & 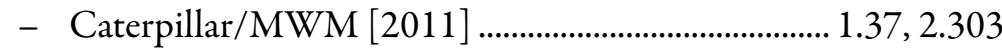 \\
\hline & $2011] \ldots \ldots . .5 .62$ \\
\hline & - Xella/H+H $[2$ \\
\hline & - Barclays Bank/Egg Credit Ca \\
\hline & $\begin{array}{r}\text { - Deutsche Börse/NYSE Euronext [2012] } \ldots \ldots \ldots \ldots \ldots . .4 .2 \\
8.112,8.113,8.115,8.119,8.1 \\
8.123,8.156,8 .\end{array}$ \\
\hline & - $\mathrm{RBI} / \mathrm{EFG} \mathrm{F}$ \\
\hline & - Birla/Colur \\
\hline 1.6 & $\begin{aligned}- & \text { West } \\
& {[201}\end{aligned}$ \\
\hline & - West \\
\hline & $\begin{aligned}- & \text { Sea } \\
& \text { Elec }\end{aligned}$ \\
\hline & ......8.83, 8.84 \\
\hline & $\operatorname{ts}[2011] \ldots \ldots \ldots . . .4 .182$ \\
\hline 1.62 & 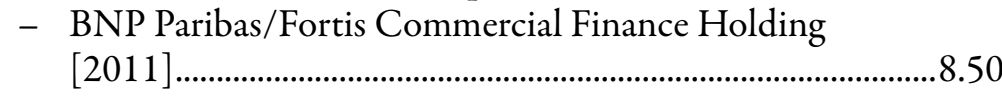 \\
\hline 1.62 & - Microsoft/Skype [2011]....................... 1.100, 3.184, 4.122, 8.381, \\
\hline M.631 & $\begin{aligned}- & \text { Tel } \\
& {[20}\end{aligned}$ \\
\hline & $-\mathrm{BM}$ \\
\hline & $-\mathrm{HB}$ \\
\hline & - IAG/BMI [ \\
\hline & hiversal Music Group \\
\hline
\end{tabular}




\begin{tabular}{|c|c|}
\hline & 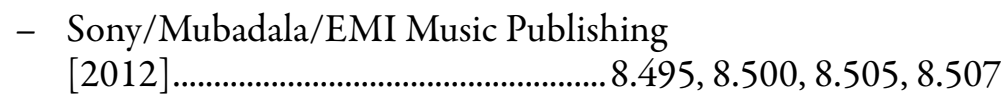 \\
\hline & - Outokumpu/Inoxum [2012] .............1.116, 4.159, \\
\hline & $\begin{array}{l}\text { Euler Hermes/MAPFRE/MAPFRE CC [2012]......8.88, 8.91, } \\
8.93\end{array}$ \\
\hline 6497 & $\begin{array}{r}\text { - Hutchison 3G Austria/Orange Austria }[2012] \text {.........4.55, 4.93, } \\
4.177,7.183,7.289,8.311,8.340\end{array}$ \\
\hline .6502 & $\begin{array}{l}\text { - London Stock Exchange Group/LCH Clearnet Group } \\
\text { Limited }[2012] \ldots \ldots \ldots \ldots \ldots \ldots \ldots \ldots \ldots \ldots \ldots \ldots \ldots \ldots \ldots \ldots \ldots \ldots . . .2 .303,2.315,8.156\end{array}$ \\
\hline 6521 & national/Meiji Yasuda Life Insurance/ \\
\hline 41 & 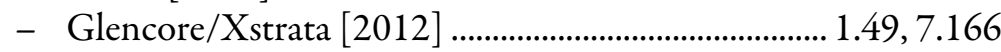 \\
\hline & rient/Gemalto/JV [2012] ............. \\
\hline & .......... 1.10 \\
\hline 6 & $\begin{array}{r}\text { - Vodafone/ } \\
8\end{array}$ \\
\hline & - US \\
\hline & $\begin{array}{l}\text { olio and Brokerag } \\
012] \ldots \ldots \ldots \ldots \ldots . . .8 .8\end{array}$ \\
\hline & - Rya \\
\hline & - Syn \\
\hline & - Syn \\
\hline & 2] \\
\hline 5 & aceuticals OTC (II) \\
\hline 167 & da Life Insu \\
\hline$M$ & $\begin{array}{l}\text { Indsey Group } \\
\ldots . . .10 . . .8 .101,8.102,8.103,8.104,8.106\end{array}$ \\
\hline M.6789 & $\begin{array}{l}\text { earson/Penguin Random House } \\
\text { 8.516, 8.520, 8.522, 8.524 }\end{array}$ \\
\hline M.6791 & - The Walt Disney Company/Lucasfilm [2012].... \\
\hline & 1.116 \\
\hline & ГIM/JV [2015]....... \\
\hline & $\begin{array}{l}8.19,8.21,8.26,8.32,8.42,8.44 \\
\text { a Business }[2013] \ldots \ldots \ldots \ldots \ldots . .3 .189\end{array}$ \\
\hline
\end{tabular}




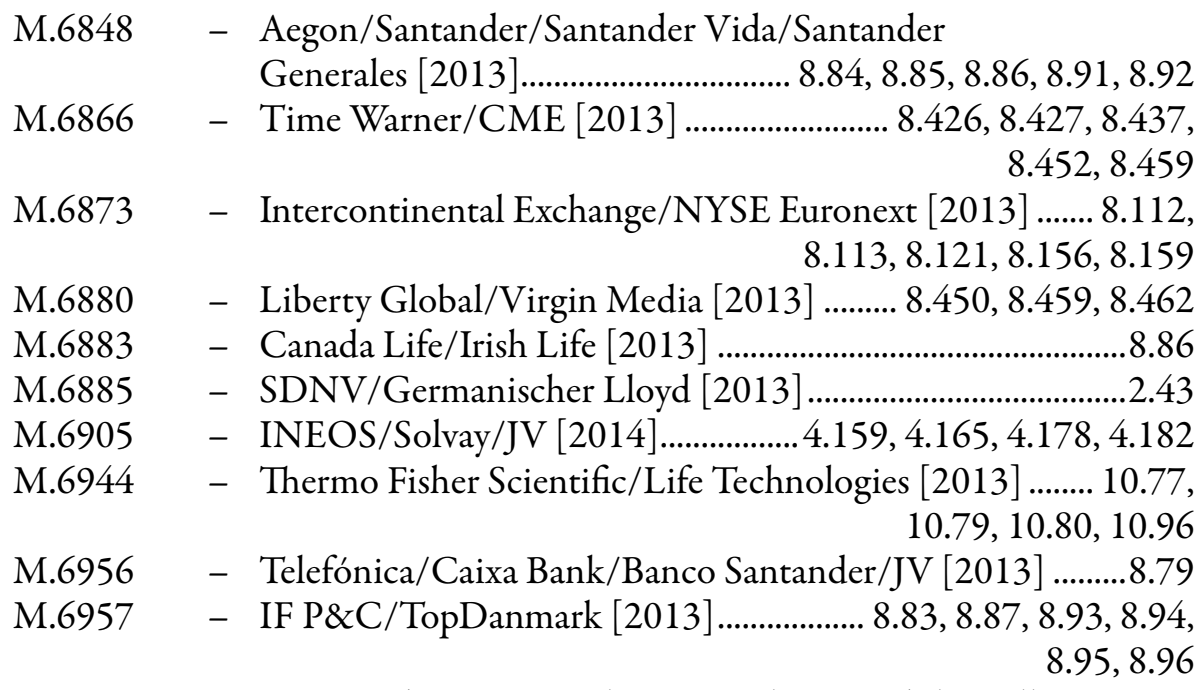

M.6967 - BNP Paribas Fortis/Belgacom/Belgian Mobile Wallet [2013]

M.6990 - Vodafone/Kabel Deutschland [2013]........ 8.249, 8.258, 8.263, $8.272,8.274,8.311,8.315,8.318,8.336,8.349$

M.6992 - Hutchison 3G UK/Telefónica Ireland [2014] ............4.55, 4.93,

M.7000 - Liberty Global/Ziggo [2018] ........... 1.100, 7.55, 7.248, 8.292 $8.355,8.437,8.443,8.450,8.457,8.458$

M.7018 - Telefónica Deutschland/E-Plus [2014] ........1.100, 3.301, 4.55, $4.93,4.147,4.152,4.177,7.183,7.268$, $7.278,8.292,7.307,7.309,8.311$

M.7023 - Publicis/Omnicom [2014] .................................................... 4.179

M.7044 - Blackstone/Goldman Sachs/Rothesay [2013]......... 2.150, 8.84

M.7047 - Microsoft/Nokia [2013] ................................ 3.287, 8.381, 8.384

M.7054 - Cemex/Holcim Assets [2014] .............................................. 3.305

M.7061 - Huntsman Corporation/Equity Interests Held by Rockwood Holdings [2014] 3.162

M.7078 - Santander Consumer Finance/El Corte Ingles/ Financiera El Corte Ingles [2014] ...................................8.29, 8.61

M.7109 - Deutsche Telecom/GTS [2014]...................8.275-8.276, 8.262, $8.278,8.355$

M.7182 - Visteon Corporation/Automotive Electronics Business of Johnson Controls [2014]

M.7184 - Marine Harvest/Morpol [2014] ............3.161, 6.45, 6.76, 6.236 
M.7194 - Liberty Global/Corelio/W\&W/De Vijver Media [2015] ........ $2.283,4.257,4.276-4.277,7.171,7.186,7.282$, $8.437,8.438,8.452$

M.7204 - Rothesay Life/MetLife Assurance [2014]..............................8.84 M.7217 - Facebook/WhatsApp [2014] .......................3.281-3.282, 3.286, $3.343,4.247,4.145,6.70,8.379,8.380,8.381,8.384$, $8.385,8.393,8.394$

M.7220 - Chiquita/Fyffes [2014] 7.193

M.7231 - Vodafone/ONO [2014]............................................8.315, 8.449

M.7233 - Allianz/Going Concern of Unipolsai Assicurazioni [2014] .................................................. 8.83, 8.88, 8.89, 8.93, 8.95

M.7241 - Advent International/Bain Capital Investors/Nets Holding [2014]. $8.62,8.64,8.66,8.67$

M.7252 - Holcim/Lafarge [2014].............................3.335, 7.6, 7.61, 7.232

M.7259 - Carphone Warehouse/Dixons [2014] ................................. 8.303

M.7265 - Zimmer/Biomet [2015] ......................................................... 4.202

M.7268 - CSAV/HGV/Kühne Maritime/Hapag-Lloyd AG

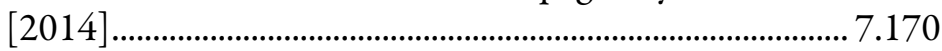

M.7275 - Novartis/GlaxoSmithKline Oncology Business [2015] ....1.97, $2.114,4.202,4.215,7.125$

M.7276 - GlaxoSmithKline/Novartis Vaccines Business (excl. Influenza)/Novartis Consumer Health Business [2015] $3.133,3.154,4.202$

M.7278 - General Electric/Alstom (Thermal Power - Renewable Power \& Grid Business) [2015]......... 1.97, 4.150, 4.152, 4.179, $4.180,4.181,4.202,4.219,7.6,7.162$

M.7282 - Liberty Global/Discovery/All3Media [2014] .................... 3.343

M.7288 - Viacom/Channel 5 Broadcasting [2014] .............................. 8.454

M.7290 - Apple/Beats [2014]............................................................... 8.421

M.7292 - DEMB/Mondelez/Charger OpCo [2015]..3.65, 3.232, 3.346

M.7313 - Telefónica/DTS [2004]............................................................. 3.343

M.7318 - Rosneft/Morgan Stanley Global Oil Merchanting Unit [2014] 3.298

M.7326 - Medtronic/Covidien [2014]...................................... 1.97, 4.213

M.7333 - Alitalia/Etihad [2014]................................................ 4.85, 7.188

M.7353 - Airbus/Safran/JV [2014].........................................................

M.7408 - Cargill/ADM Chocolate Business [2015] ................. 3.336, 5.62

M.7419 - TeliaSonera/Telenor/JV [2015] .................................. 4.55, 4.177

M.7421 - Orange/Jazztel [2015] ...........4.253, 7.185, 7.282, 8.337, 8.338, $8.339,8.342,8.343,8.349$ 


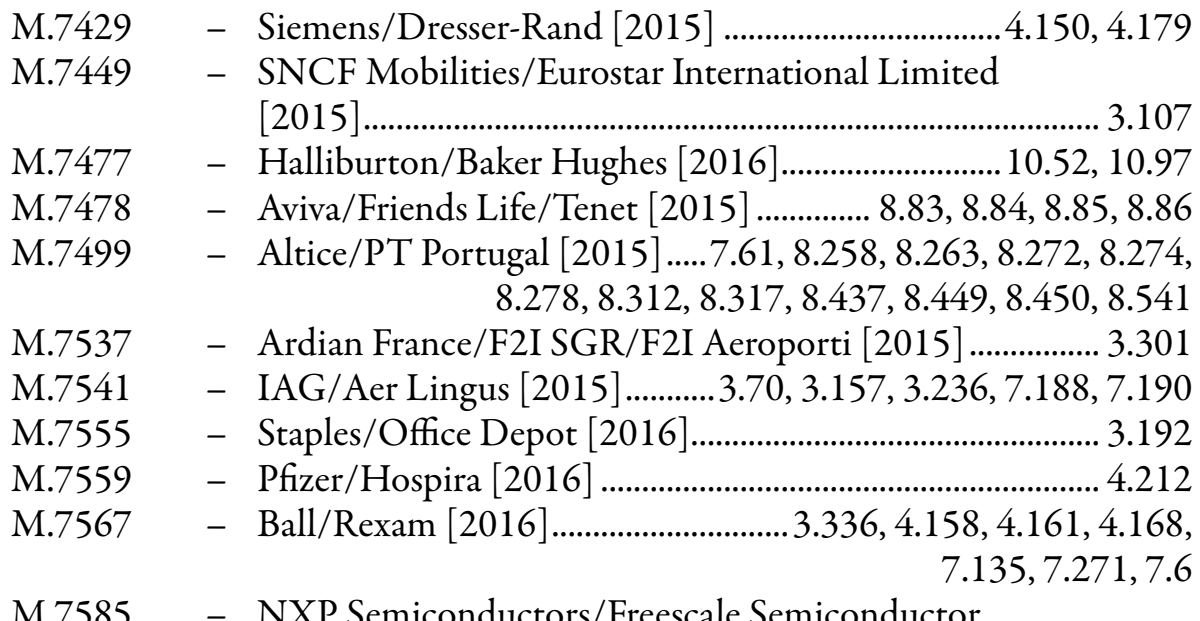
[2015] $7.61,7.237$

M.7612 - Hutchison 3G UK/Telefónica UK [2016].... 1.102, 4.55, 4.57, $4.143,4.177,4.184,6.207,7.69,7.184,8.247,8.292,8.294$, $8.296,8.297,8.299,8.300,8.302,8.303,8.304,8.311$

M.7631 - Royal Dutch Shell/BG Group [2015] ............................... 3.158

M.7637 - Liberty Global/BASE Belgium [2016]..........7.67, 7.160, 8.291

M.7671 - OBI/bauMax Standort Steyr [2015].................................. 2.114

M.7688 - Intel/Altera [2015]............................................................. 3.158

M.7711 - Advent International/Bain Capital/ICBPI [2015] ...8.61, 8.70

M.7724 - ASL/Arianespace [2016] ............................................4.258, 7.193

M.7744 - HeidelbergCement/Italcementi [2016] ............................... 7.128

M.7746 - Teva/Allergan [2016] ..............................................................4.93

M.7758 - Hutchison 3G Italy/Wind/JV [2016] ............ 4.55, 4.93, 4.147,

M.7759 - Pfizer/Hospira [2015].....

M.7801 - Wabtec/Faiveley Transport [2016].............. 4.244, 7.112, 7.134

M.7850 - EDF/CGN/NNB Group of Companies [2016] ...2.37, 2.112, $5.24,5.62$

M.7866 - Activision Blizzard/King [2016]..............................8.431, 8.432

M.7872 - Novartis/GSK (ofatumumab auto-immune indications) [2015]

M.7873 - Worldline/Equens/Paysquare [2016] ...7.171, 8.62, 8.64, 8.65, $8.66,8.67,8.69,8.76,8.139,8.173$

M.7878 - HeidelbergCement/Schwenk/Cemex Hungary/ Cemex Croatia [2017] ......................................... 1.100, 3.301, 3.335, 4.87, $4.161,4.164,7.174$ 


\begin{tabular}{|c|c|}
\hline & - AB InBev/SABMiller [2016].............................7.232, 7.6, 7.160 \\
\hline 79 & $\begin{array}{l}\text { - Marriott International/Starwood Hote } \\
\text { Worldwide [2016] }\end{array}$ \\
\hline 79 & Boehringer Ingelheim/Sanofi Animal Health Business \\
\hline$[.79]$ & - Sanofi/Boeringher Ingelheim Healthcare Business \\
\hline 1.793 & $\begin{array}{r}\text { - ABP Group/Fane Valley Group/Slaney Foods [2016] ... 3.161, } \\
3.172,4.161,4.233,4.235\end{array}$ \\
\hline 79 & 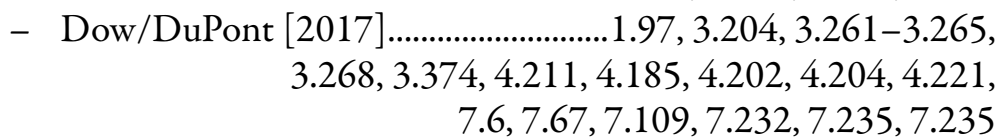 \\
\hline 87026 & 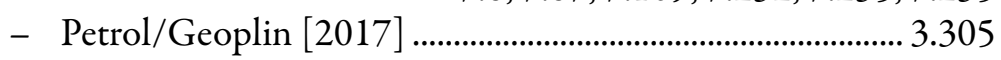 \\
\hline 1.7 & $\begin{array}{l}\text { Crédit Mutuel/GE Capital's Factoring and } \\
\text { Equipment [2016] ..................................................8.4 }\end{array}$ \\
\hline & - Banco Santander Totta/BANIF [2016] .....................3.301, 8.30 \\
\hline & - Norwegian \\
\hline 0 & - EGB/GP [2016]. \\
\hline 62 & - ChemChina/Syngenta [2017]. \\
\hline & - ADM/Wilmar/C \\
\hline & - Mylan/Me \\
\hline & $\begin{array}{r}\text { - Vodafone/ } \\
4.6,4.1\end{array}$ \\
\hline & \\
\hline & .99 \\
\hline & - Altic \\
\hline M.7995 & $\begin{array}{r}\text { - Deutsche Börse/London Stock } \\
3.277,3.357,4 \\
8.114,8,\end{array}$ \\
\hline & .........8.88 \\
\hline M.8 & $\begin{array}{r}\text { - Sony/Sony-ATV [2016]........8.495, 8.499, } 8.501,8.503,8.504, \\
8.505,8.506,8.507\end{array}$ \\
\hline & .350 \\
\hline & $126,3.158$ \\
\hline & ........... 4.206 \\
\hline & $\begin{array}{r}\text { - Advent Inter } \\
\text { Intesa Sanpa }\end{array}$ \\
\hline
\end{tabular}




\begin{tabular}{|c|c|}
\hline & $\begin{array}{r}\text { - Bayer/Monsanto }[2018] \ldots \ldots \ldots . .1 .7,1.97,3.266-3.268,3.374, \\
4.13,4.185,4.194,4.202,4.208,4.223,4.246,4.247 \\
4.62,6.83,7.162,7.163,7.205,7.232,7.235,7.261, \\
7.269,7.280,7.283,7.67,7.68,10.77,10.101\end{array}$ \\
\hline 1 & - SEB/WMF Group [2016]... \\
\hline & 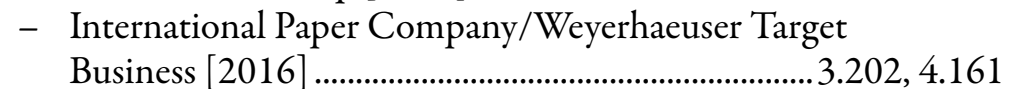 \\
\hline .8102 & - Valeo/FTE Group [2017].................... \\
\hline & $\begin{array}{r}- \text { Microsoft/LinkedIn } \\
7.178,7.182\end{array}$ \\
\hline .8 & Siemens/Gamesa [20 \\
\hline & MasterCard/ \\
\hline & - Danone/The \\
\hline I.8 & $\begin{aligned}- & \text { Canon/Tosh } \\
& {[2019] \ldots \ldots \ldots . . . . . }\end{aligned}$ \\
\hline & 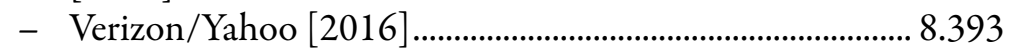 \\
\hline & - Merck/Sigr \\
\hline & - Avnet/Prem \\
\hline & $\begin{array}{l}\text { - Emerson Electric/Pentair (Valves a } \\
\text { Business) [2017]................................. }\end{array}$ \\
\hline 8207 & - Knorr-Brem \\
\hline .8 & - Facebook/WhatsApp [2017]..... \\
\hline .8 & - Rol \\
\hline 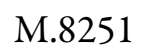 & - Bite \\
\hline & $-\mathrm{HI}$ \\
\hline .8 & - NN Group/Delta Lloyd [2017]............... 8.42, 8.83, 8.8 \\
\hline .8258 & - Advent International/Morpho [2017]................ $7.48,8.6$ \\
\hline .82 & ral Electric Company/LM Wind Power Holding \\
\hline & 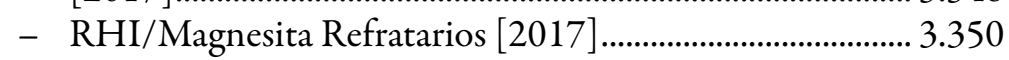 \\
\hline 1.82 & $\begin{array}{r}\text { - Nordic Capital/Intrum Justitia [2017] } \ldots \ldots . . .3 .343,8.54,8.134, \\
8.55,8.56,8.57,8.169\end{array}$ \\
\hline & onductors [2018] 3. \\
\hline & $, 7.181,7$ \\
\hline & er Silica [2017] ....... 4.123 \\
\hline & ......... 3.343, 8.437, 8.454 \\
\hline & $\begin{aligned}- & \text { Amundi/Credit A } \\
& {[2017] \ldots \ldots \ldots \ldots . . .5 .31 }\end{aligned}$ \\
\hline
\end{tabular}




\begin{tabular}{|c|c|}
\hline & 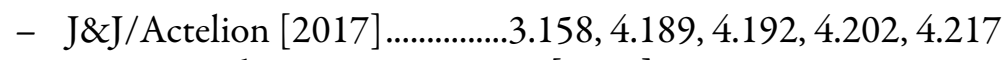 \\
\hline & $\begin{array}{r}\text { DNB/Nordea/Luminor Group [2017].. 8.28, 8.29, 8.30, 8.31, } \\
8.33,8.34,8.35,8.40,8.41,8.58\end{array}$ \\
\hline & 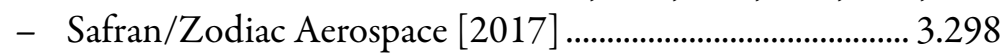 \\
\hline & al Electric Company/LM Wind Power Hold \\
\hline 8444 & ArcelorMittal/Ilva [2018] ........................ 4.7, 4.13, 7.68, 7.204, \\
\hline & Peugeot/Opel [2017] \\
\hline & 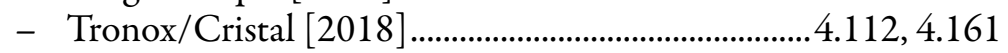 \\
\hline & 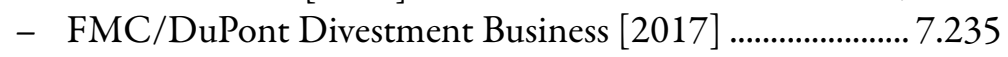 \\
\hline & $\cos [2017] \ldots . . .3 .249$ \\
\hline & 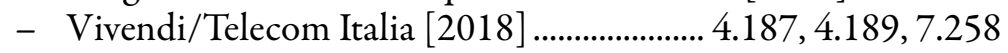 \\
\hline & - Praxair/Linde $[2018] \ldots \ldots \ldots \ldots \ldots \ldots \ldots \ldots \ldots . . .3 .298,4$ \\
\hline & ABP Food Group/Fane Valley/Linden Food \\
\hline & Ava \\
\hline & $-\mathrm{BD} /$ \\
\hline & 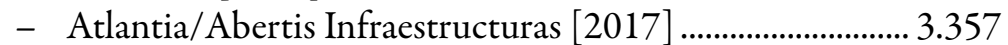 \\
\hline & - Banco Santander/Banco Popular Group [2017] f.......8.2 8. \\
\hline & {$[2018] \ldots \ldots$.} \\
\hline & Allianz/LV General Insurance Businesses [20 \\
\hline 3 & - Lufthansa/Certain Air Berlin Assets [2017] .......4.4, 4 \\
\hline & $-\mathrm{CV}$ \\
\hline & {$[2018] \ldots . . . . .$.} \\
\hline & - Discovery/Scripps [2018] ..................2.274, 4.121, \\
\hline 77 & $\begin{array}{r}- \text { Siemens/A } \\
4.13\end{array}$ \\
\hline M.8713 & - Tata Steel/ThyssenKrupp/JV [2019]3.1 \\
\hline & 300 \\
\hline & $\begin{array}{r}\text { - Daimler/BMW/Car Sharing JV [2018] .... 4.112, 7.181, 7.182, } \\
7.250\end{array}$ \\
\hline & $4,8.105$ \\
\hline & $\begin{array}{r}\text { - The Walt Disney Company/Twenty-First Century Fox [2018] } \\
8.248,8.426,8.437,8.443,8.444,8.460,8.461,8.468,8.470\end{array}$ \\
\hline
\end{tabular}




\begin{tabular}{|c|c|}
\hline 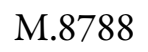 & $8]$... \\
\hline .8792 & 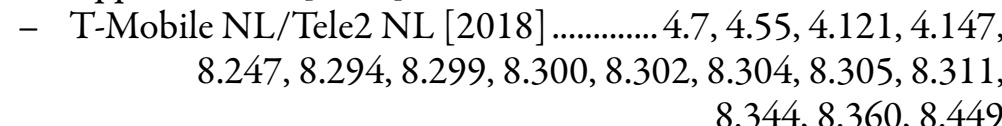 \\
\hline .8808 & $\begin{array}{r}\text { - } \text { T-Mobile Austria/UPC Austria [2018] } \\
8.315,8.340,8.3 . \ldots . . .8 .275-8.276 \\
8.8 .343,8.355\end{array}$ \\
\hline 1.8837 & $\begin{array}{r}\text { - Blackstone/Thomson Reuters F\&R Business [2018] } \ldots \ldots \ldots . .8 .36 \text {, } \\
8.38,8.40,8.41,8.47,8.83,8.120,8.122,8.124,8.125\end{array}$ \\
\hline .8851 & - BASF/Bayer Divestment \\
\hline & - Vodafone/Certain Liberty Global Assets \\
\hline 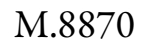 & - E.ON/Innogy [2019] \\
\hline .8871 & - RWE/E.ON Assets [2019].... \\
\hline .8900 & $\begin{array}{l}\text { - Wieland/Aurubis Rolled Produc } \\
{[2019] \ldots \ldots \ldots \ldots \ldots \ldots \ldots . . . . . .17 .17,4.130,4}\end{array}$ \\
\hline & - AXA Group/Roland [2018].... \\
\hline & - KME/MKM \\
\hline & - Liberty Global/D \\
\hline & - Nidec/Whirlpool (Embraco business) [2019] \\
\hline & - Takeda/Shire $[2020] \ldots . .$. \\
\hline & $\begin{array}{r}\text { - Delta } \\
\text { Virgi }\end{array}$ \\
\hline & $8] \ldots . . . . . . .8 .8$. \\
\hline & $-\mathrm{PK}$ \\
\hline & - Mars/Anic \\
\hline & - Generali CEE/AS [2018]... \\
\hline 1.9 & $\begin{array}{l}\text { - } \text { Telia Company/Bonnier Broadcasting Holding } \\
{[2019] \ldots . .4 .283,7.55,7.171,7.186,7.248,7.272,7.280,7.282} \\
\quad 7.297,7.304,8.216,8.344,8.437,8.444,8.453,8.454,8.460\end{array}$ \\
\hline . & $179,4.203,7.119,7.276$ \\
\hline & - Carlyle/Sedgwick [2018].... \\
\hline 1.9190 & $\begin{array}{l}\text { - Marsh \& McLennan Companies/J } \\
\text { Thompson Group [2019] ........... 8.9 }\end{array}$ \\
\hline 2 & SmithKline/Pfizer Consumer Healthcare \\
\hline & $-\mathrm{Co}$ \\
\hline & S Group [2019]....... \\
\hline & BMS/Celgene [2019] \\
\hline
\end{tabular}




\begin{tabular}{|c|c|}
\hline & 4.202 \\
\hline 7 & - FIS/Worldpay [2019] ........................ 8.60, 8.62, 8.64, 8.66, 8.71, $8.72,8.135$ \\
\hline 6 & 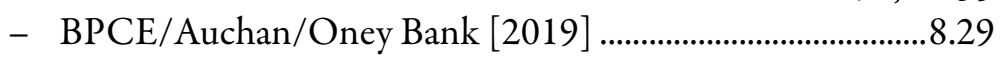 \\
\hline & Allied Irish Banks/First Data Corporation/Semeral \\
\hline M.9398 & - Centerbridge Partners/Amtrust Corporate Member \\
\hline 9408 & - Assa Abloy/Agta Record [2020]............................................. 4.253 \\
\hline & - Aurubis/Metallo Group Holding [2020]...... \\
\hline & $\begin{array}{l}\text { - Kuwait Petroleum Belgium/U Car Services/VP Oil/ } \\
\text { Certain Businesses From Uhoda [2019]............................... } 4.231\end{array}$ \\
\hline 21 & 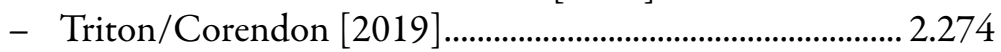 \\
\hline .9432 & - Allianz Holdings/Legal and General Insurance \\
\hline & - Global Payments/TSYS [2019]........................... 8.67, 8.69, 8.135 \\
\hline 61 & - Abbvie/Allergan [2019].... \\
\hline 9489 & - Air Canada/Transat [2021]. \\
\hline .9517 & - Mylan/UpJohn [2020] ....... \\
\hline M.9531 & $\begin{array}{l}\text { - Assicurazioni Generali/Seguradoras Unidas/ } \\
\text { Advancecare [2019] ..................................................8.110, 8.111 }\end{array}$ \\
\hline & - J\&J/Tachosil $[2020] \ldots \ldots \ldots . . . . .$. \\
\hline$M$ & $\begin{array}{r}\text { - Elanco Animal Health/Bayer Animal Health [2020] ..... 4.202, } \\
4.208,4.218,7.125\end{array}$ \\
\hline & - PKN Orlen/Ruch [2020] .................................... \\
\hline M.9564 & - LSEG/Refinitiv Business [2020]................... 4.2 \\
\hline 9660 & - Google/Fitbit $[2020] \ldots \ldots \ldots \ldots . . . .4 .244,7.179,7.18$ \\
\hline M.96 & - Vodafone Italia/TIM/INWIT JV [2020] $\begin{array}{r}\ldots . . .5 .17,5.24,5.25 \\
7.289, \\
\text {, } 7.294,7.304\end{array}$ \\
\hline & - Altice/Omers/Allianz/Covage [2020] .................................. 4.253 \\
\hline & - FCA/PSA $[2020] \ldots$. \\
\hline M.9744 & - MasterCard/Nets $[2020] \ldots \ldots \ldots \ldots . . .8 .75,8.76,8.77,8.141,8.175$ \\
\hline M.9759 & 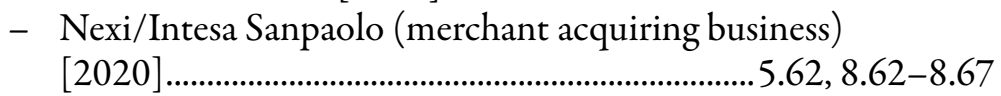 \\
\hline M. & .............8.135, 8.142 \\
\hline M.9779 & $\begin{array}{r}\text { - Alstom/Bombardier Transportation }[2020] \\
7.153,7.28 . .4 .179,4.253,7.289,7.294\end{array}$ \\
\hline & - Aldi/FPLPH Assets [2021] .......... \\
\hline
\end{tabular}


M.9886 - Salling Group/Tesco Polska [2020]

$.2 .274,4.231$

M.9894 - Mobilux/Conforama France [2020]

$2.294,4.231$

\section{Joint venture cases}

JV.1 - Telia/Telenor/Schibsted [1998] ................................8.372, 8.392

JV.12 - Ericsson/Nokia/Psion/Motorola [1998] .....................2.92, 2.97

JV.15 - BT/AT\&T [1999].............................. 8.279, 8.283, 8.284, 8.318

JV.25 - Sony/Time Warner/CDNow [1999] ................................. 8.416

JV.37 - BSkyB/Kirch Pay TV [2000]............ 4.237, 7.287, 7.298, 8.440

JV.47 - Canal+/Lagardere/Liberty Media/Multithematique

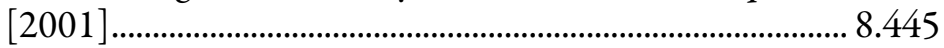

JV.48 - Vodafone/Vivendi/Canal Plus [2000]..................... 8.372, 8.392

JV.50 - Blackstone/CDPQ/Kabel Baden-Württemberg [2000] ....2.79

JV.51 - Bertelsmann/Mondadori/BOL Italia [2000]........... 2.75, 2.170

JV.54 - Smith\&Nephew/Beiersdorf/JV [2001] .............................. 2.179

JV.55 - Hutchinson/RCPM/ECT [2001] .......................2.88, 2.91, 4.72

JV.57 - TPS [2002] ……………………………………..... 2.88, 8.440

\section{Antitrust Cases}

26.267 - Dyestuffs [1969] ....................................................................... 10.8

29.725 - Wood Pulp [1984]..................................................................... 10.8

31.043 - TetraPak (II) [1991] ....................................................... 3.173

33.440 - Warner Lambert/Gillette [1992] .............................................. 1.51

35.617 - Phoenix/Global One [1996]................................................... 8.283

$36.539-$ British Interactive Broadcasting/Open [1999] .................... 8.460

37.398 - Joint selling of the commercial rights to the UEFA

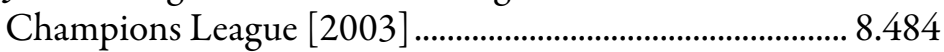

37.451 - Deutsche Telekom AG [2003] ............................................. 8.253

37.576 - UEFA Broadcasting Regulations [2001] ...................8.484, 8.485

$37.792-$ Microsoft [2004].................................................................... 7.182

38.287 - Telenor/Canal+/Canal Digital [2003]................................. 8.460

38.784 - Wanadoo España/Telefónica [2007] ..........................8.347, 8.350

39.654 - Reuters Instrument Codes [2012] ....................................... 8.124

39.736 - Siemens/Areva [2012] .............................................................. 1.116

39.740 - Google Search (Shopping) [2017] ........................................ 8.386

40.153 - E-book MFNs and related matters (Amazon e-books) [2017] ..................................................................... 8.424-8.425 


\section{ECSC Treaty Merger Cases}

ECSC.1031 - US/Sollac/Bamesa [1993] ........................................................4.

ECSC.1351 - Usinor/Arbed/Aceralia [2001] ...................................................4.36 